\title{
Decentralized Energy Studies: Bibliography
}

James M. Ohi

Charles T. Unseld

Alice Levine

Jo Ann Silversmith
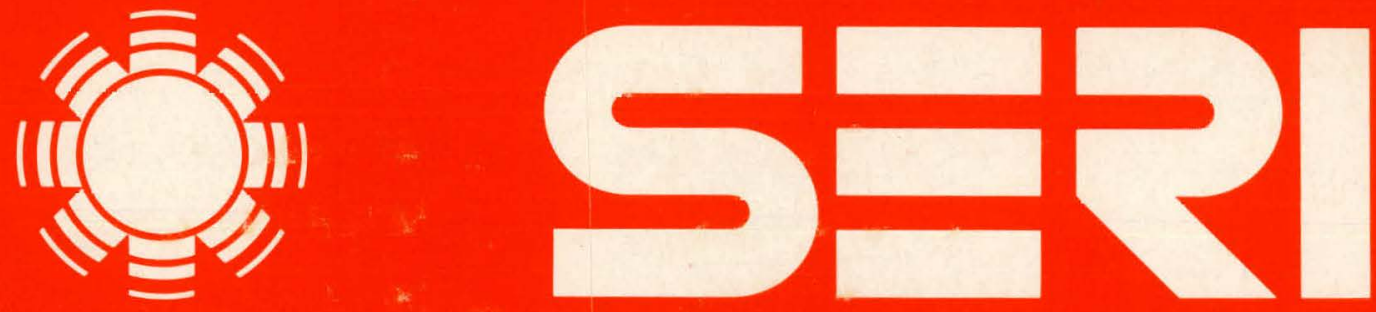

Solar Energy Research Institute A Division of Midwest Research Institute

1617 Cole Boulevard

Golden, Colorado 80401

Operated for the U.S. Department of Energy under Contract No. EG-77-C-01-4042 


\section{DISCLAIMER}

This report was prepared as an account of work sponsored by an agency of the United States Government. Neither the United States Government nor any agency Thereof, nor any of their employees, makes any warranty, express or implied, or assumes any legal liability or responsibility for the accuracy, completeness, or usefulness of any information, apparatus, product, or process disclosed, or represents that its use would not infringe privately owned rights. Reference herein to any specific commercial product, process, or service by trade name, trademark, manufacturer, or otherwise does not necessarily constitute or imply its endorsement, recommendation, or favoring by the United States Government or any agency thereof. The views and opinions of authors expressed herein do not necessarily state or reflect those of the United States Government or any agency thereof. 


\section{DISCLAIMER}

Portions of this document may be illegible in electronic image products. Images are produced from the best available original document. 
Printed in the United States of America Available from:

National Technical Information Service

U.S. Department of Commerce

5285 Port Royal Road

Springfield, VA 22161

Price:

Microfiche $\$ 3.00$

Printed Copy $\$ 5.25$

\section{NOTICE}

This report was prepared as an account of work sponsored by the United States Government. Neither the United States nor the United States Department of Energy, nor any of their employees, nor any of their contractors, subcontractors, or their employees, makes any warranty, express or implied, or assumes any legal liability or responsibility for the accuracy, completeness or usefulness of any information, apparatus, product or process disclosed, or represents that its use would not infringe privately owned rights. 


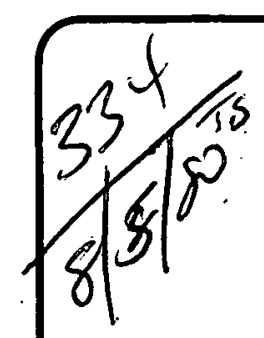

$$
\begin{aligned}
& \text { SERI/RR-744-448 } \\
& \text { UC CATEGORY : UC-58b }
\end{aligned}
$$

\section{DECENTRALIZED ENERGY STUDIES:} BIBL IOGRAPHY

JAMES M. OHI

CHARLES T. UNSELD

AL ICE LEVINE

JO ANN SILVERSMITH

MAY 1980

\section{MASTER .}

PREPARED UNDER TASK NO. 5629.99

\section{Solar Energy Research Institute}

A Division of Mirwest Research Institute

1617 Cole Boulevard

Golden, Coloradn 80401

Preparcd for the

U.S. Department of Energy

Contract No. EG-77-C-01-4042

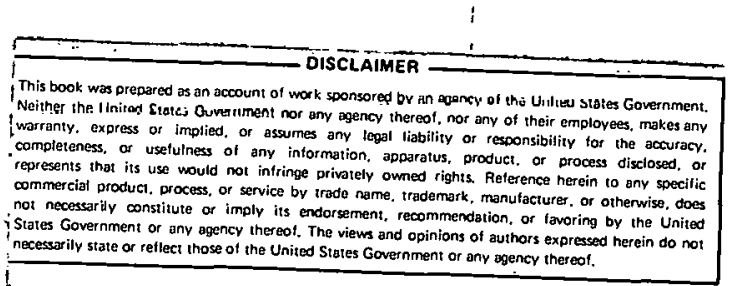




\section{THIS PAGE \\ WAS INTENTIONALLY \\ LEFT BLANK}




\section{PREP ACE}

This bibliography was prepared as part of the Decentralized Energy Studies task at the Solar Energy Research Institute (SERI) to provide an extensive listing of publications concerned with decentralized energy systems. The bibliography is divided into topical and geographical sections (i.e. national, multistate region, state, and community) in order to provide some indication of the relative amount of attention that has been given to each level of study and to make the bibliography more usable by researchers and government officials. This divison of listings should permit researchers and of ficials at each level of government to discover relatively quickly what other researchers and governmental jurisdictions have done or are doing in the area of decentralized energy systems. In addition, there is a section on articles by and about Amory Lovins, who has played a pivotal role in bringing decentralization to the attention of the nation. Periodicals devoted to the gencral topic of decentralized energy systems and bibliographies/directories are included.

The authors attempted to compile a comprehensive listing while exercising some selectivity in dealing with a topic that is far ranging and difficult to delimit. In trying to meet the competing requirements of comprehensiveness and selectivity, the authors judgment, undoubtedly, will be questioned. Questioning in the form of suggestions on additions and deletions are welcome, since the bibliography will be revised periodically to maintain its currency in a rapidly expanding subject area. Please communicate any suggestions to any of the coauthors at SERI.

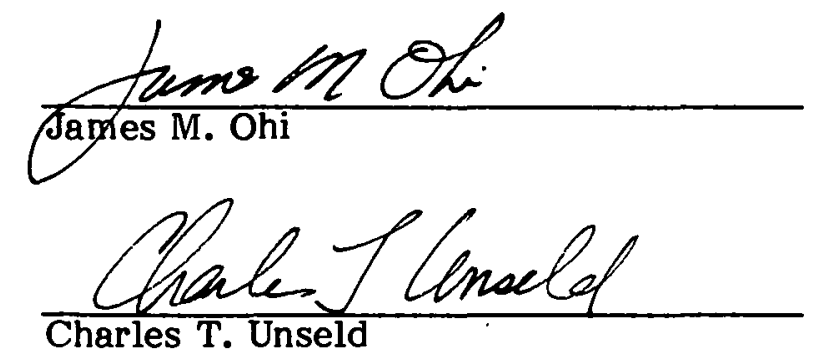

Approved for:

SOLAR ENERGY RESEARCH INSTITUTE

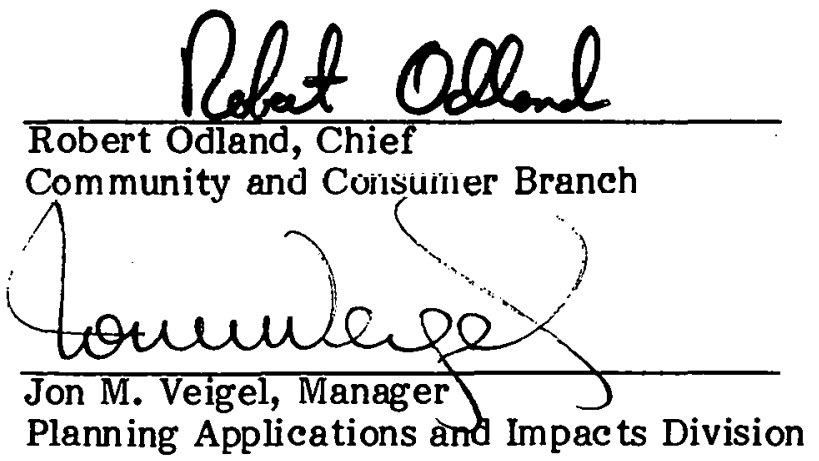


THIS PAGE

\section{WAS INTENTIONALLY \\ LEFT BLANK}




\section{SUMMARY}

\section{OBJECTIVE}

This report provides a comprehensive bibliography on decentralized energy systems.

\section{DISCUSSION}

The literature on decentralized energy systems provides a rich source of social, economic, technical, and ecological thought that will assist the United States in making a transition to renewable energy sources. The bibliography was compiled during a research task on decentralized energy systems and provides a reference to that report.

The primary audience intended for this bibliography comprises policy makers and researchers working on decentralized energy systems. The need for an increased understanding of the complex societal issues that relate to policy making in this area is clear. It is also anticipated that local government of ficials, grassroots groups, and others involved in the planning and implementation of decentralized energy systems will find this bibliography of value. However, this is not primarily a listing of "how to" publications.

Decentralized planning and control involve much more than energy, and some of the works listed address issues other than energy. By the same token, the bibliography should be of use to audiences interested in making policy for planning, and implementing other types of decentralized and community-scale projects.

This literature ranges from highly abstract and theoretical works to very practical "nuts and bolts" manuals. No categorization along this dimension has been provided. The ca tegorization scheme employed reflects issue areas that derive in large part from SERI approaches to conducting research in this area. Sections 2.0 through 6.0 reflect somewhat bounded conceptual categories or research areas-values and lifestyles; institutional analysis; land use or more general community planning; environmental and social impact analysis; and economics or feasibility assessment. Section 7.0 reflects different costs of categorization by geographic scale, ranging from the community to the aggregate national scale. Section $\mathbf{8 . 0}$ reflects the extent to which one person, Amory B. Lovins, has influenced this area as a writer and as the object of criticism, praises, or controversy. Section 9.0 lists periodicals that regularly carry articles of interest to people in the community energy system field, while Section 10.0 lists other bibliographies and direc tories.

\section{CONCLUSIONS AND RECOMMENDATIONS}

It is the intent of the Community and Consumer Branch staff at SERI to update this bibliography periodically. Contributions to the task are welcome. 


\section{THIS PAGE}

\section{WAS INTENTIONALLY \\ LEFT BLANK}




\section{TABLE OF CONTENTS}

Page

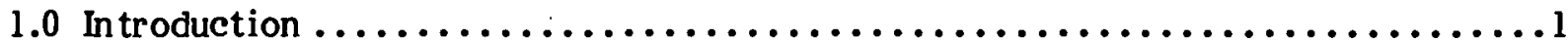

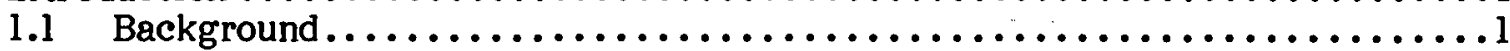

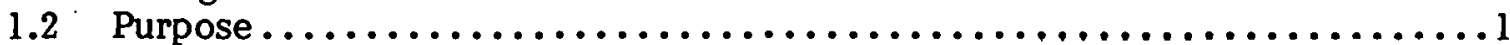

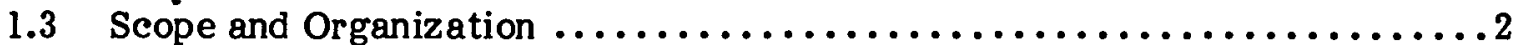

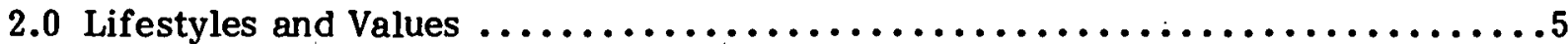

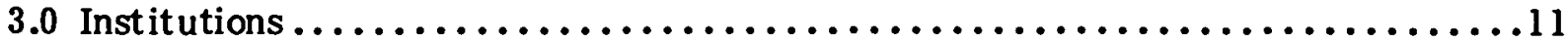

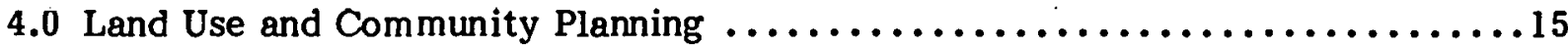

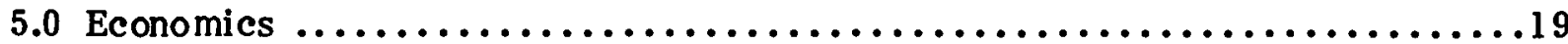

6.0 Environmental and Social Impact Assessment $\ldots \ldots \ldots \ldots \ldots \ldots \ldots \ldots \ldots \ldots$

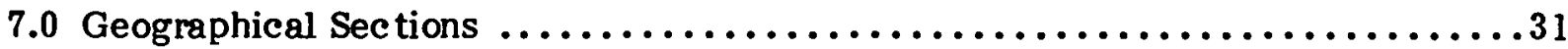

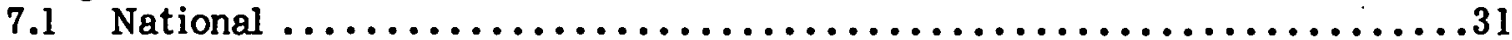

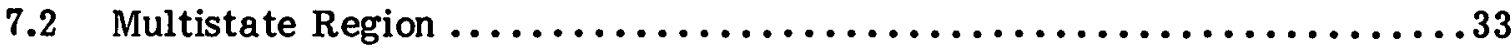

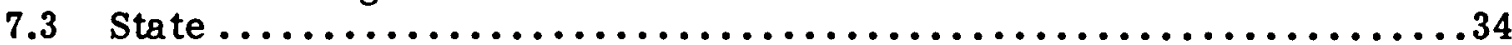

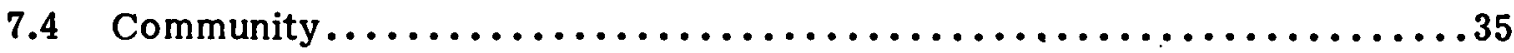

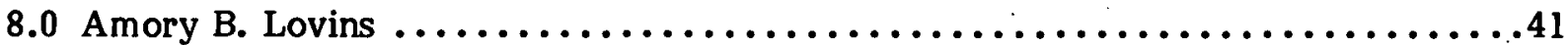

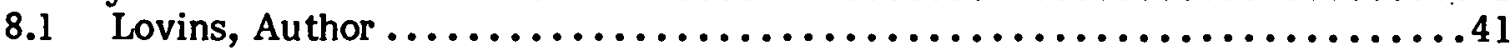

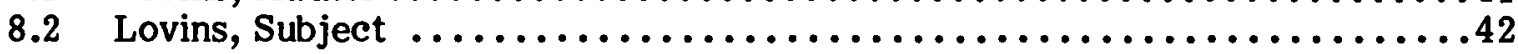

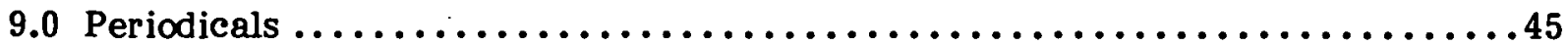

10.0 Bibliographies/Directories $\ldots \ldots \ldots \ldots \ldots \ldots \ldots \ldots \ldots \ldots \ldots \ldots \ldots \ldots \ldots \ldots \ldots$ 


\section{SECTION 1.0}

\section{INTRODUCTION}

\section{I BACKGROUND}

The ability of the U.S. political system to maintain a long-term balance between decentralized and centralized centers of power has been a critical factor in the success, thus far, of American democracy. The decentralization-centralization agrument shaped the Constitution and continues to provide a useful frame of reference through which to articulate and analyze critical political, economic, and social questions. Perhaps the most critical question today concerns energy and how to make the economic, social, and political transition from dependence upon depletable energy sources to reliance upon those renewable sources that will sustain American society. Recently, energy policy debate has focused a great deal of attention upon decentralized energy systems and how they might assist the United States in making this transition. (Odland et al. 1979a,b).

The potential of small, decentralized energy systems based on renewable sources remained largely ignored until Amory Lovins (1976) published his seminal article on the "soft energy path." The debate engendered by Lovins' demarcation of the soft and hard paths toward alternative energy futures has been lively, and research in decentralized energy systems has flourished.* The decentralization-centralization debate is being argued in a variety of ways on many fronts, from congressional committees (U.S. Senate 1977) to city councils as well as industrial promotional groups (Quinn and Ohi 1980) and religious councils (National Council of Churches of Christ 1978).

The term decentralization, when applied to energy systems, usually evokes an image of small, community-owned and operated facilities based on renewable energy sources. It is a term associated with such American ideals as local autonomy, personal self-reliance, and Jeffersonian social pluralism (Maize 1979). Decentralization, however, is an elusive term because it is used to depict at various times a process, a desired end-state, a dynamic equilibrium, and a set of values that direct preferences for particular qualities of energy systems. The term is used to evoke a loosely ordered set of economic, technological, social, political, institutional, and environmental qualities and values that, when taken together, describe energy systems quite different from those that prevail today.

\subsection{PURPOSE}

The authors cumpiled this bibliography to provide a quick reference to the literature in the decentralized energy systems area. Interest in this area is intense and growing

*The "hard" path relies on "rapid expansion of high lechnologies" that will require even greater centralization of energy systems, but it is more difficult to relate decentralized technologies directly to the "soft" path. The soft path can consist of soft and hard technologies as long as the latter are deployed as transitional technologies. One quality of soft technologies is the matching of geographic distribution to end-use needs (Lovins 1976, p. 78), an advantage of ten cited for decentralization. In another publication (1977), Lovins identifies technologies based on renewable energy sources with decentralized technologies. 
rapidly, resulting in a proliferation of articles, books, research papers, and newsletters. Moreover, there are myriad topical areas and disciplinary interests relevant to research on and implementation of these systems. All of this has resulted in a valuable crossfertilization of ideas among interested persons, but simultaneously makes it increasingly difficult to remain abreast of relevant literature. This difficulty is compounded by the fact that many important ideas are found in such "fugitive" literature as unpublished papers or newsletters, small journals, or government publications with limited distribution. Thus, the authors recognized a need to compile the literature that was collected during their research and to dissemina te this information to colleagues working on the same issues.

The primary audience intended for this bibliography includes policy makers and researchers working on decentralized energy systems. The need for an increased understanding of the complex societal issues that relate to decentrulized energy systems' policy making is clear. It is also anticipated that local government of ficials, grassroots groups, and others involved in the planning and implementation of decentralized energy systems will find this bibliography of value, however, this is not primarily a listing of "how to" publicutions.

It should be noted that decentralized planning and control involves much more than energy, and some of the works listed do not directly address the issue of energy. By the same token, the bibliography should be of use to audiences interested in making policy for planning and implementing other types of decentralized projects.

\subsection{SCOPE AND ORGANIZATION}

This literature ranges from highly abstract and theoretical works to very practical "nuts and bolts" manuals. No categorization along this dimension has been provided. The categorization scheme employed reflects issue areas that derive in large part from the authnrs' approaches to conducting research in this area. Sections 2.0 through 6.0 reflect somewhat bounded conceptual categories or reseurch areas valuos and lifestyles; institutional analysis; land use or more general community planning; environmental and social impact analysis; and economics or feasibility assessment. Section 7.0 reflects categorization by geographic scale, ranging from the community to the aggregate national scale. Section $\mathbf{8 . 0}$ reflects the extent to which one person, Amory B. Lovins, has influenced this area as a writer and as the object of criticism, praise, or controversy. Section 9.0 lists periodicals that regularly carry articles of interest to people in the decentralized energy system field, while Section 10.0 lists other bibliographies and direc tories.

It is the intent of the authors to update this bibliography periodically: Contributions to the task are welcome. 


\section{RETERENCES}

Lovins, Amory B. 1976 (October). "Energy Strategy: The Road Not Taken?" Foreign Affairs. Vol. 55 (No. 1): pp. 66-96.

Lovins, Amory. 1977. "Limits to Energy Conversion: The Case for Decentralized Technologies." Dennis L. Meadows, ed. Alternatives to Growth I: A Search for Sustainable Futures. Cambridge, MA: Ballinger; pp. 59-78.

Maize, Kennedy. 1979 (July). Chicago Sun Times; p. 3.

National Council of Churches of Christ. 1978 (November). Policy Statement on the Ethical Implications of Energy Production and Use (Proposal). Draft.

Odland, Robert; Meunier, Richard; Ohi, James; Pollock, Peter. 1979a (January). Decentralized Energy Studies: Progress Report No. 1. SERI/PR-53-167. Golden, CO: Solar Energy Research Institute.

Odland, Robert; Meunier, Richard; Ohi, James; Pollock, Peter. 1979b (April). Decentralized Energy Studies: Progress Report No. 2. SERI/PR-53-220. Golden, CO: Solar Energy Research Institute.

Quinn, James; Ohi, James. 1980 (May). Decentralized Energy Studies: A Compendium of U.S. Studies, Programs, and Projects. SERI/RR-354-450. Golden, CO: Solar Energy Research Institute.

U.S. Senate. 1977 (December). Alternative Long-Range Energy Studies. Joint Hearing before the Select Committee on Small Business and the Committee on Interior and Insular Affairs, 94th Congress. 9 December 1976. Washington, DC: Government Printing Office. 


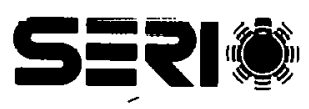




\section{SECTION 2.0}

\section{LIFESTYYLS AND VALUES}

Values and lifestyles are relatively new as energy research topics. Yet, individuals, and to some extent communities, have for some time recognized that their choices of technologies can promote or hinder their attempts to achieve a desirable quality and style of life. To ignore this dimension of community energy systems implementation is to treat energy as an end in itself, to treat decentralized systems as mere technological fixes for technological problems.

Common sense and empirical evidence indicate that much of today's groundswell of activity related to decentralized energy planning has been inspired by an attempt on the part of some individuals and communities to capture their energy future, and to achieve such values as self-reliance, community cohesion, or a less destructive relationship with the natural environment.

The literature in this section covers a broad range of approaches to understanding lifestyles, values, and energy. Necessarily this listing is not comprehensive, but representative of the diversity of thinking to be discovered among the numerous people who are turning their attention to understanding how energy can be better used to achieve social ends.

Abt, Clark C. 1977. "Energy Shortages and Changing Life Styles." Technological Forecasting and Social Change. Vol. 10: pp. 113-119.

Adams, Martin R. 1979. "Energy, Liberty, and the Pursuit of Happiness." Presented at First Annual Conference on Community Renewable Energy Systems; Boulder, CO; August 20-21. Golden, CO: Solar Energy Research Institute. Proceedings in preparation.

Allen, Hobert. 1977. "Towards a Primary Life-style." Dennis L. Meadows, ed. Alternatives to Growth I A Search for Sustainable Futures. Cambridge, MA: Ballinger; pp. 313-325.

Allport, G.; Vernon, P. F.; I.indzey, G. 1860. Manual: Study of Values. Boston, MA: Houghton Mifflin.

Americain Academy of Arts and Sciences. 1977 (February). "Technological Choices in the Context of Social Values." Bulletin. Vol. 30: pp. 4-14.

Arnstein, S. R.; Christakis, A. N.; Wolf, C. P. 1975. "A Futures-Creative Paradigm." S. R. Arnstein and A. N. Christakis, eds. Perspectives on Technology Assessment. Jerusalem, Israel: Science and Technology Publishers.

Baier, K.; Rescher, N., eds. 1969. Values and the Future. New York: The Free Press. 
Benson, James W., ed. 1979 (October). Values Forum: Exploring Energy, Technology, Politics and Values. Number 1. Fairfax, VA: Institute for Ecological Policies.

Berg, Mark; Chen, Kan; Zissis, George. 1976. "A Value-Oriented Policy Generation Methodology for Technology Assessment." Technological Forecasting and Social Change. Vol. 8: pp. 401-420

Berry, Wendell. 1977. The Unsettling of America: Culture and Agriculture. New York: Avon Books.

Bond, C. E. 1978 (August). "Solar Energy and Social Values." Karl W. Baer and Gregory E. Franta, eds. Proceedings of the 1978 Annual Meeting of the American Section of the Liternational Solar Energy Snciety, Inc. Annual Meeting, American Section, ISES; Denver, CO; August 28-31. Newark, DE: American Section, ISES; pp. 443445.

Boulding, K. 1966. Human Values on the Spaceship Earth. New York: National Council of Churches of Christ in the U.3.A.

Brand, Stewart. "Voluntary Simplicity Follow-up and Comment." 1977 (September). CoEvolution Quarterly. Vol. 15: pp. 52-59.

Campbell, Angus. 1974. "Measuring the Quulily of Life." Michigan Business Review. Vol. 26 (No. 1): pp. 25-27.

Campbell, Rex R.; Wade, Jerry L. 1972. Society and Environment: The Coming Collision. Boston, MA: Allyn and Bacon, Inc.

Cantril, Hadley. 1965. The Pattern of Human Concerns. New Brunswick, NJ: Rutgers University Press.

Catton, William R., Jr.; Dunlap, Riley E. 1978 (February). "Environmental Bũiology: A New Paradigm." The American Sociologist. Vol. 13: pp. 4l-49.

1978 (November). "Paradigms, Theories, and the Primacy of the HEPNEP Distinction." The American Sociologist. Vol. 13: pp. 256-259.

Christensen, Bente Lis; Nфrgard, Jørgen Stig. 1976. "Social Values and the Limits to Growth." Technological Forecasting and Social Change. Vol. 9: pp. 411-423.

Commoner, B. 1976. The Poverty of Power. New York: Alfred A. Knopf.

Commoner, B.; Boksenbaum, H.; Corr, M., eds. 1975. Energy and Human Welfare: A Critical Analysis; Human Welfare: The End Use for Power. Vol. III. New York: MacMillan.

Dunlap, Riley E.; Catton, William R., Jr. 1979. "Environmental Sociology." Annual Review of Sociology. Vol. 5.

Dunlap, Riley E.; Van Liere, Kent D. 1978. "The 'New Environmental Paradigm.' " Journal of Environmental Education. Vol. 9: Summer; pp. 10-19. 
Edelstein, Michael. 1979. "The Real Energy Crisis: Lifestyle and the Prospect of Changing Patterns of Energy Use." Howard B. Radest, ed. The Social Dimensions of Energy Options. Mahweh, NJ: Ramapo Papers; pp. 17-35.

Elgin, Duane; Mitchell, Arnold. 1977 (June). "Voluntary Simplicity (3)." CoEvolution Quarterly. Vol. 14: pp. 4-19.

Ford, Andrew. 1979 (July/August). "Is Smaller Better?" Public Power. Vol. 37: pp. 28-31.

Frankel, Gene. 1979 (June). "Solar Energy and the Decentralized Vision." Presented at a workshop on the Social Impacts of Energy Decentralization; Institute on Man and Science, Rensselaerville, NY; June 13-16.

Fritsch, A. J.; et al. 1977. 99 Ways to a Simple Lifestyle. Garden City, NY: Anchor Books.

Gerson, Elihu M. 1976 (October). "On 'Quality of Life.' " American Sociological Review. Vol. 4l: pp. 793-806.

Governing Board of the National Council of the Churches of Christ. 1979 (May). Policy Statement on the Ethical Implications of Energy Production and Use. New York, NY.

Gregg, Richard. 1977 (June). "Voluntary Simplicity (1)." CoEvolution Quarterly. Vol. 14: pp. 20-27.

Hammond, K. R.; Adelman, L. 1976. "Science, Values and Human Judgment." Science. Vol. 194: pp. 389-396.

Harman, Willis W. 1977 (February). "The Coming Transformation." The Futurist. pp. 5-12.

1978 (April). "Knowledge and the World of the Future." Franklin Foundation lecture given at Georgia State University, Atlanta, GA; April 25.

Henderson, Carter. 1978 (IVlay). "Ihe Frugality Phenomenon." Bulletin of the Atomic Scientists. Vol. 34 (No. 5): pp. 24-27.

Henderson, Hazel. 1976 (October). "Efficiency and Other Myths of Technological Culture." Second International Congress of the In ternational Society for Technological Assessment; Ann Arbor, MI; October 28.

1978. Creating Alternative Futures. New York: Berkeley Publishing Corporation.

- 1979 (July-August). "Coming of the Solar Age." Resurgence. Vol. 10 (No. 2): pp. 6-9.

Hornick, William F.; Enk, Gordon A. 1979. Value Issues in Technological Assessment. Rensselaerville, NY: The Institute on Man and Science.

Ilich, I. 1974. Energy and Equity. New York: Perennial. 
Inglehart, Ronald. 1977. The Silent Revolution: Changing Values and Political Styles Among Western Publics. Princeton, NJ: Princeton University Press.

Kahn, Herman; Brown, Jerry; Lovins, Amory. 1977. "The New Class." CoEvolution Quarterly. Spring; pp. 8-39.

Kahn, H.; Wiener, A. J., eds. 1974. American Values: Past and Future; Values, Attitudes and Lifestyles in a Changing World. Vol. I. Hastings, NY: Hudson Institute.

King, Llewellyn. 1979 (March). "Energy and the New Class." The Energy Daily. pp. 3-6.

Love, Sam. 1974 (December). "The Overconnected Society." The Futurist. Vol. 8 (No. 6): pp. 293-298.

Martino, Joseph P.; Lenz, Ralph C., Jr.; Chen, Kuei-Lin. 1978. "Description of Society." Technology Assessment: An Appraisal of the State of the Art. Final report to the Nallunlul Science Funndutioñ. Daytun, OII! University of Dayton Rcscarch Institute.

Mazur, Allan; Rosa, Eugene. 1974 (November). "Energy and Lifestyle." Science. Vol. 186: pp. 607-610.

Meier, Richard L.; Crane, Janet E. 1978 (March/April). "Less is More." Society. Vol. 15 (No. 3): pp. 55-63.

Milstein, Jeff rey S. 1978. Soft and Hard Energy Paths: What People on the Street Think. Washington, DC: U.S. Department of Energy, Office of Conservation and Solar Applications.

Meunier, Richard E. 1978. "Image and Reality in the Energy Sector." Draft. Oak Rice, TN: Institute for Energy Analysis.

Mitchell, A. 1973. Life Ways and Life Styles. Long Range Planning Report No. 500. Menlo Park, CA: Stanford Research Institute.

Moffitt, Leonard C. 1975 (November). "Value Implications for Public Planning: Some Thoughts and Questions." AIP Journal. Vol. 41 (No. 6): pp. 397-405.

Morrison, Denton E. 1978. (February). "The Growth Equity Debate: Parties, Perspectives, Issues, and Prospects." Presented at 144 th Annual Meeting of the American Association for the Advancement of Science; Washington, DC; February 13.

Nader, Laura; et al. 1977. Report of the Consumption, Location, and Occupational Patterns Resource Group of the Synthesis Panel. NAS/NRC, Committee on Nuclear and Alternative Energy Systems.

Nader, Laura; Beckerman, Stephen. 1978. "Energy as it Relates to the Quality and Style of Life." Annual Review of Energy. Vol. 3 (No. 1): pp. 1-28.

Nicosia, Francesco M.; Mayer, Robert N. 1976 (September). "Toward a Sociology of Consumption." Journal of Consumer Research. Vol. 3: pp. 65-75. 
Odonnell, R. M. 1978. New Hampshire Forums on Energy and the Aging. Durham, NH: University System of New Hampshire, Graduate School.

Paehlke, Bob; Schrecker, Ted, eds. 1979. Alternatives: Perspectives on Society and Environment. Vol. 8 (No. 2). Peterborough, Ont.: Trent University.

Phillips, Michael. 1977 (June). "SRI is Wrong About Voluntary Simplicity." CoEvolution Quarterly. Vol. 14: pp. 32-34.

Pierotti, Anne; Fritsch, Albert J. 1977. Lifestyle Index. Washington, DC: Citizen's Energy Project.

Rokeach, Milton. 1973. The Nature of Human Values. New York: The Free Press. - 1976. Beliefs, Attitudes and Values. San Francisco, CA: Jossey-Bass Publishers.

Sansom, Robert L. 1976. The New American Dream Machine: Toward a Simpler Lifestyle in an Environmental Age. Garden City, NY: Anchor Books.

Sayre, Kenneth, ed. 1977. Values in the Electric Power Industry. Notre Dame, IN: University of Notre Dame Press.

Schumacher, E. F. 1974 (December). "Economics Should Begin with People, Not Goods." The Futurist. pp. 274-275.

Schwartz, Seymour I. 1977. Energy Conserving Lifestyles. Final report to the California Energy Resources Conservation and Development Commission. Davis, CA: University of California.

Shama, Avraham; Jacobs, Ken. 1979. Social Values and Solar Energy Policy: The Policy Maker and the Advocate. SERI/RR-51-329. Golden, CO: Solar Energy Research Institute.

Smelser, Neil J. 1974. Energy Restriction, Consumption, and Social Stratification. Submitted to Sociopolitical Risk/Impact Resource Group. NAS/NRC, Committee on Nuclear and Alternative Energy Systems.

Stanford University. 1979. Alternative Energy Futures: An Assessment of U.S. Options to 2025. Stanford, CA: Institute for Energy Studies.

Taviss, Irene. 1973. "Futurology and the Sludy of Values." Search for Alternatives: Public Policy and the Study of the Future. Cambridge, MA: Winthrop; pp. 98-101.

Todd, John. 1977. "Technologies for a New Lifestyle." Dennis L. Meadows, ed. Alternatives to Growth E A Search for Sustainable Futures. Cambridge, $\overline{\mathrm{MA}}$ Ballinger; pp. 45-57.

Tribe, L. H.; Schelling, C. S.; Voss, J., eds. 1976. When Values Conflict: Essays on Environmental Analysis, Discourse and Decision. Cambridge, MA: Ballinger. 
U.S. House of Representatives. 1977. Energy Demand, Conservation Potential and Probable Lifestyle Changes. Hearings before the Subcommittee on Advanced Energy Technologies and Energy Conservation Research, Development, and Demonstration; Committee on Science and Technolugy; 95th Congress, lst Session; April 4 and 5; No. 35. Washing ton, DC: U.S. Government Printing Office.

Unseld, Charles T. 1978. "Social Impact Assessment of Energy Policy: Behavior, Lifestyle, Values, and Priorities." Seymour Warkov, ed. Energy Policy in the United States: Social and Behavioral Dimensions. New York: Praeger.

Van Liere, Kent D.; Dunlap, Riley E. 1979. "The Social Bases of Environmental Concern: A Review of Hypotheses, Explanations and Empirical Evidence." Annual Meeting of the Southern Sociological Society, Atlanta, GA.

Vlachos, Evan. 1979. Energy Paradigms: The Basis for Decentralization Viewpoints. Fort Collins, CO: Department of Sociology, Colorado State University; mimeographed.

Winner, Langdon. 1977. Autonomous Technology: Technics Out of Control as a Theme in Political Thought. Cambridge, MA: The MIT Press.

1979 (June). "Decentralization: Hardware and Politics." Presented at a workshop on the Social Impacts of Energy Decentralization, Institute on Man and Science, Rensselaerville, NY; June 13-16. 


\section{SECTION 3.0}

\section{INSTITUTIONS}

The implementation of decentralized energy planning requires attention to the role of institutions, as participants in the planning and implementation process and as recipients of potential impacts. A shift to a more decentralized sustainable energy future undoubtedly will bring about changes in various social institutions, yet the kinds of changes that are coming are now largely a matter of speculation.

This section contains literature discussing a variety of institutional issues relevant to decentralized energy planning. The potential roles of traditional institutions such as utilities and financial organizations in decentralized energy planning, as well as impacts on these institutions, are discussed in this literature. Other topics include possibilities for new institutions such as cooperatives, opportunities for citizen participation and control in energy planning efforts, and a variety of legal and political issues relevant to decentralized energy planning.

Adams, Richard N. 1979 (June). "Social Power Structure and Energy Decentralization." Presented at a workshop on the Social Impacts of Energy Decentralization; Institute on Man and Science, Rensselaerville, NY; June 13-16.

American Society of Planning Officials. 1976. Institutional Factors Influencing the Acceptance of Community Energy Systems and Energy-Efficient Community Design: Public Planning, Administration, and Regulations. Chicago, IL: American Society of Planning Of ficials.

Bronfman, Ben; et al. 1979. Legal Institutional Issues in the Use of Decentralized Solar Energy Systems. Draft. Oak Ridge, TN: Oak Ridge National Laboratory.

Caldwell, Lynton K. 1976. "Energy and the Structure of Social Institutions." Human Ecology. Vol. 4: pp. 31-45.

Collins, W. D.; Hunciker, K. M. n.d. On-Site Solar Energy and Public Utilities Regulation. Pasadena, CA: Jet Propulsion Laboratory.

Daly, Herman E. 1976 (January). "Energy Demand Forecasting: Prediction or Planning?" Journal of the American Institute of Planners. pp. 4-15.

Davis, Joan; Mauch, Samuel. 1977. "Strategies for Societal Development." Dennis L. Meadows, ed. Alternatives to Growth I: A Search for Sustainable Futures. Cambridge, MA: Ballinger; pp. 217-242.

Gerlach, Luther P. 197.9 (June). "Energy Wars and Social Change: The Impact of Social Movements on Technology and Society." Presented at a Workshop on the Social Impacts of Energy Decentralization; Institute of Man and Science, Rensselaerville, NY; June 13-16. 
Gilmer, Robert W. 1979. The Social Control of Energy: A Case for the Promise of Decentralized Solar Technologies. Draft. Oak Ridge, TN: Institute for Energy Analysis, Associated Universities.

Gilmer, Robert W.; Meunier, Richard E. 1979. Electric Utilities and Solar Energy: The Service Contract in a New Social Context. Oak Ridge, TN: Institute for Energy Analysis, Associa ted Universities.

Goldberg, David H. 1978 (November). Office of Smail-Scale Technology: Recommendations on Structure and Function. Montpelier, VT: Program Planning/Development Associa tes.

Goldemith, Edward. 1977. "Settlements and Social Stability." Dennis L. Meadows, ed. Alternatives to Growth I: A Search for Sustainable Futures. Cambricge, MA: Ballinger; Pp. 331-341.

Kahn, Herman. 1973. "The Alternative World Futures Approach." Search for Alternatives: Public Policy and the Study of the Future. Cambridge, MA: Winthrop.

Klausner, Samuel Z.; Burch, William R., Jr.; Edelstein, Robert H. 1976. Projecting the Social Institutional Impacts of Energy Consumption. Report submitted to Sociopolitical Risk/Impact Resource Group, NAS/NRC, Committee on Nuclear and Alternative Energy Syslems.

LaPorte, Todd R. 1978 (July). "Nuclear Waste: Increasing Scale and Sociological Impacts." Science. Vol. 201: pp. 22-28.

Lipsky, Michael. 1968. Radical Decentralization: A Response to American Planning Dilemmas. Reprint No. 28. Madison, WI: Institute for Research on Poverty, University of $W$ isconsin.

Mauch, Sam; et al'. Decentralized Energy Studies: Swiss Naliuilal Plan, Societal Values. SER I/R R-744-453. Transla ted by Phillip S. MeKnight. Golden, CO: Solar Energy Research Institute; for theoming.

Messing, Marc; Friesema, H. Paul; Murell, David. 1979 (March). Centralized Power: An Examination of the Effects of Centralized and Decentralized Electric Generating Systems on the Political Authorities of Local Governments. Washington, DC: Environmental Policy Institute.

Meunier, Richard E.; Silversmith, Jo. Organizational Forms for Ownership and Management of Decentralized Renewable Energy Systems. SERI/TR-354-312. Golden, CO: Solar Energy Research Institute; for thcoming.

The MITRE Corporation. 1979 (May). Accelerating the Commercialization of Solar Energy: The Role of State and Local Governments. MTR-79W00182. Bedford, MA: The MITRE Corporation.

Morrison, Denton E. 1978 (September). "Energy, Appropriate Technology, and International Interdependence." Presented at the Annual Meeting of the Society for the Study of Social Problems, San Francisco, CA. 
Nelkin, Dorothy; Fallows, Susan. 1976 (October). "The Policies of Participation in Energy Policy." Draft. Report of the Sociological Risks/Impacts Resources Group. Washing ton, DC: Committee on Nuclear and Alternative Energy Systems.

O'Toole, R. P.; et al. 1975 (October). Institutional Aspects of On-Site Solar Electric Power Generation. Engineering Memorandum 393-276. Pasadena, CA: Jet Propulsion Laboratory, Calif ornia Institute of Technology.

Peelle, E. 1979. "Social Costs of Decentralized Solar Technologies: Social Considerations Relative to Impacts of Decentralized Solar Technologies." Manuscript. Oak Ridge, TN: Oak Ridge National Laboratory.

Schwartz, P. S. 1977. "The Growing Conflict Between Central Control and Individual Freedom." Assessment of Future National and International Problem Areas. Vol. II-B. Menlo Park, CA: Center for the Study of Social Policy, Stanford Research Institute.

Schweitzer, Martin. 1980. Review of Legal and Institutional Issues in the Use of Decentralized Solar Energy Systems. ORNL/TM-7078. Oak Ridge, TN: Oak Ridge National Labora tory.

Stillman, Peter G. 1978 (March). "Social Implications of Solar Energy." "Proceedings of Helios: From Myth to Solar Energy Conference; Albany, NY; March 16-18; Vol. 1: p. 64 .

Taubenfield, Rita F.; Taubenfield, Howard J. 1977. "Wind Energy: Legal Issues and Legal Barriers." Southwestern Law Journal. Vol. 31 (No. 5): Winter; pp. 1053-1093.

Tug well, Franklin. 1973. Search for Alternatives: Public Policy and the Study of the Future. Cambrioge, MA: Winthrop.

Unseld, Charles T.; Wolf, C. P. 1978. "Institutional Impacts of Nuclear and Alternative Energy Systems." Report of the Sociopolitical Risk/Impact Resource Group. Draft. Washing ton, DC: Committee on Nuclear and Alternative Energy Systems.

Untract, Marcia R. 1977 (October). "Sociological Implications of Efficient Energy Use." Rocco A. Fazzolare and Craig B. Smith. Energy Use Management: Proceedings of the International Conference on Energy Use Management. Tucson, AZ; October 24-28.

American Institute of Architects Research Corporation. 1976. Site Planning for Solar Energy Utilization: Solar Dwelling Design Concepts. Washington, DC: U.S. Government Printing Office.

Wilson, Jones, Morton, Lynch, Inc. 1976. Legal Alternatives, Implications and Financing of Solar Heating and Cooling by a Municipal Corporation. Santa Clara, CA. 


\section{SE키*}




\section{SECTION 4.0}

\section{LAND USE AND COMMUNTTY PLANNDNG}

This section of the bibliography lists publications that deal with land use and community planning relationships. Solar and decentralized energy systems present both opportunities and difficulties for efficient land use and innovative community planning. Because energy is a vital ingredient of all community systems, it provides a medium for community analysis as well as a means to attain community land use and planning objectives. On the other hand, many communities were developed without carefully considering the relationships among energy, land use, and community planning, so their transition to greater reliance up on solar and decentralized energy systems will be difficult. These opportunities and difficulties are beginning to receive the attention of many people, and their research will play an important role in guiding communities toward renewable energy futures.

Bacon, Edmund N. 1973 (July/August). "Energy and Land Use." Urban Land. pp. 13-16.

Bryant, Nevin A. 1978. Solar Potential Inventory and Modelling. Pasadena, CA: Jet Propulsion Laboratory.

Byme, Robert M. 1978 (April). The Impact of Energy Costs and Supply Prospects on Land Development Practices. Washington, DC: Urban Land Institute.

Carroll, T. Owen; Nathans, Robert. 1979. "Land Use Configurations and the Utilization of Distributed Energy Technology." Distributed Energy Systems in California's Future. Vol. II. HCP/P7405-02. Washington, DC: U. S. Department of Energy.

Carroll, T. Owen; Nathans, Robert; Palmedo, Phillip F.; Stern, Robert. 1976. The Planner's Energy Workbook. BNL 50683. Brookhaven National Laboratory and the State University of New York. Washington, DC: Federal Energy Administration.

Center for Landscape Architectural Education and Research. n.d. Options for Passive Energy Conservation in Site Design. Washington, DC: U. S. Department of Energy.

Christensen, Kathleen. 1976 (September). Social Impacts of Land Development: An Initial Approach for Estimating Impacts on Neighborhood Usages and Perceptions. Washing ton, DC: Urban Land Institute.

Clinginun, W. H. 1979. Field Survey of Solar High Temperature Industrial Process Heat. El Segundo, CA: Aerospace Corporation.

The Conference Board, Committee on the Investment Impact of Urban Trends. 1974 (November). Suburban Sprawl and the Energy Situation. New York: The Conference Board.

- 1974. Urban Trends and the Energy Situation. Report No. 642. New York: The Confercnee Board. 
Ellis, George. 1978 (June). "The Roof tops of San Fernando." Solar Age. Vol 3 (No. 6).

Harrigan, R. W. 1975. Application of Solar Total Energy to a Mixed-Load Community. Albuquerque, NM: Sandia Laboratories.

Harwood, Corbin Crews. 1977. Using Land to Save Energy. Cambridge, MA: Ballinger.

Jaffe, Martin; Erley, Duncan. 1979. Protecting Solar Access to Residential Development: A Guidebook for Planning Officials. Washington, DC: U.S. Department of Housing and Urban Development, and of Energy.

Keyes, Dale L. 1976 (September). "Energy and Land Use: An Instrument of U.S. Conservation Policy." Energy Policy. pp. 226-236.

Keyes, Dale L.; Peterson, George R. 1977 (March). Metropolitan Development and Energy Consumption. Washington, DC: Urban Institute.

Knowles, Ralph L. 1974. Energy and Form: An Eculuyical Approach to Urban Growth. Cambridge, MA: MIT Press.

Knowles, Ralph L.; Berry, Richard D. 1980 (April). Solar Envelope Concepts: Moderate Density Building Applications. SERI/SP-98155-1. Golden, CO: Solar Energy Research Institute.

Marshall, B. W. 1975. Analysis of a 1000 Home Solar Total Energy Community Using Clear Air Solar Intensity. SAND-75-0097. Albuquerque, NM: Sandia Laboratories.

Mathematical Sciences Northwest, Inc. 1979 (February). Estimating Energy Impacts of Residential and Commercial Building Development: A Manual. MSNW-79-3054-3. Bellevue, WA: Mathematical Sciences Northwest, Inc.

McClemon, Charles, ed. 1977. Landscape Planning for Energy Conservation. McLean, VA: American Society of Landscape Architects Foundation.

McCoy, Hugh A.; Singer, Joseph F. 1979. "Energy 'Growth Management Systems Planning Considerations." Presented at American Institute of Planners, 61 st Annual Conference; New Orleans, LA.

Milne, Murray; et al. 1979. Three Solar Urban Futures: Characterization of a Future Community Under Three Energy Supply Scenarios. Working draft. Berkeley, CA: Lawrence Berkeley Labora tory.

Nadler, Arnold D. 1977 (October). "Planning Aspects of Direct Solar Energy Generation." Journal of the American Institute of Planners. Vol. 43 (No. 4): pp. 39-351.

Pollack, Peter. 1979 (March). The Implementation of Solar State Incentives: Land Use Planning to Ensure Solar Access. SERITR-51-163. Golden, CO: Solar Energy Research Institute. 
Real Estate Research Corporation. 1974. The Costs of Sprawl: Environmental and Economic Costs of Alternative Residential Development Patterns at the Urban Fringe. Washington, DC: U.S. Government Printing Office.

Resource Planning Associates, Inc. 1977. Comprehensive Community Planning for Energy Management and Conservation: Developing and Applying a Coordinated Approach to Energy-Rela ted Community Development. Vol. II. Washington, DC: U.S. Energy Research and Development Administration.

Roberts, James S. 1975 (September). "Energy and Land Use: Analysis of Alternative Development Patterns." Environmental Comment. pp. 3-11.

Ross, Greg. 1979. Energy Conservation in Land Use Planning. Brampton, Ontario, Canada: City of Brampton Council.

Smith, Patricia. 1979. A Methodology for Evaluating Physical Constraints on Residential Solar Energy Use. Unpublished draft. Berkeley, CA: University of California, Department of Landscape Architecture.

Twiss, Robert; et al. 1978. "Land Use Implications of a Dispersed Energy System." Distributed Energy Systems in California's Future. Vol. II. HCP/P7405-02. Washington, DC: U.S. Department of Energy.

Urban Land Institute. 1978 (March). "Solar Energy and Land Use." Environmental Comment.

U.S. Federal Energy Administration. 1976 (March). An Overview and Critical Evaluation of the Relationship Between Land Use and Energy Conservation, Technology and Economics. Washington, DC: Federal Energy Adminstration. 


\section{SE키눈}




\section{SECTION 5.0}

\section{ECONOMICS}

This section includes both theoretical and applied works concerned with the economics of decentralized and renewable energy systems. The recent interest in decentralized energy systems has been influenced enormously by what Herman Daly calls the "reorienting [of economic thought along lines more congruent with a finite physical world" (Daly 1973 , p. 7). Economists such as Daly, Kenneth Boulding, and E. F. Schum acher have helped broaden economic thought to include consideration of distributional equity, finite resources, and environmental constraints. Much of the literature addresses the development of. "steady-state" economics as a part of a larger societal "paradigm shift." The paradigm calls for living within ecological limits rather than expending ever greater energy and other resources to extend these limits to gain ever smaller increments of material wealth.

American Council for an Energy-Efficient Economy. 1979 (October). Principles and Proposals. San Francisco, CA: American Council for An Energy-Efficient Economy.

Argonne National Laboratory. n.d. Integrated Community Energy System (ICES) Commercialization Case Studies. Argonne, IL: ANL, Energy and Environmental Systems Division.

Bennett, R. B. 1978. Small Business Energy Audits. Ellensburg, WA: Central Washington State University.

Boulding, Kenneth. 1973. "The Economics of Ecology." Managing the Environment. Washington, DC: U.S. Environmental Protection Ag ency; pp. 27-30.

Bradford National Corporation; American Hydrotherm Corporation. 1978. Feasibility Assessment of a Total Energy Plant for Co-op City. Washington, DC: U.S. Department of Energy.

Burby, Raymond J., III; Bell, A. Fleming, eds. 1978. Energy and the Community. Cambridge, MA: Ballinger Publishing Co.

Daly, Herman E., ed. 1973. Toward a Steady-State Economy. San Francisco, CA: Freeman.

Daly, Herman E. 1976. "Energy Demand Forecasting: Prediction or Planning?" Human Ecology. Vol. 4: pp. 31-45.

deLaureal Engineers, Inc. 1977. Grid-Connected ICES: Preliminary Feasibility Analysis and Evaluation: Final Report; Executive Summary. Vol. 1. Washington, DC: U.S. Energy Research and Development Administration.

Feldman, Roger; Giordano, Gerard. 1979 (March/April). "Financing Dispersed Generation Projects." Public Power. pp. $31 \mathrm{ff}$. 
State of Florida. n.d. Florida Lifecycle Energy Evaluation Technique Program: Reference Manual. Tallahassee, FL: Dept. of General Services, Bureau of Construction.

Forrester, Jay. 1977. "New Perspectives on Economic Growth." Dennis L. Meadows, ed. Alternatives to Growth I: A Search for Sustainable Futures. Cambridge, MA: Ballinger; pp. 107-121.

Green, Leon, Jr. Scale of Energy Facilities: Reconciling "Small is Beautiful" with "Big is Necessary." Unpublished paper. McLean, VA: The MITRE Corporation, Metrek Division.

Henderson, Hazel. 1977. "The Cuining Economic Transition." Dennis L. Mcadows, cd. Alternatives to Growth I: A Search for Sustainable Futures. Cambridge, MA: Ballinger; pp. 123-134.

- 1978. Creating Alternative Futures: The End of Economics. New York: Berkeley Publishing Co.

- 1978 (May). "Risk, Uncertainty, and Economic Futures." Best's Review. p. 10 and passim.

1978. "Science and Technology: The Revolution from Hardware to Sof tware." Technological Forecasting and Social Change. Vol 12: pp. 317-324.

Kennedy, A. S.; Tschanz, J. F. 1978. Factors that Influence the Acceptance of Integrated Community Energy Systems. Argonne, IL: Argonne National Laboratory.

Laitos, Jan. 1980 (March). Municipal Bond Financing of Solar Energy Facilities. SERI/TR-62-191. Golden, CO: Solar Energy Research Institute.

Krawiec, Stella. 1980 (April). Economics of Selected WECS Dispersed Applications. SERI/TR-43 1-580. Golden, CO: Solar Energy Research Institute.

Magee, Judith. 1979. Down to Business. Butte, MT: National Center for Appropriate Technology.

Mixon, W. R.; et al. 1976 (December). Technology Assessment of Modular Integrated Utility Systems. Volume 2. OR NL/HUD/MIUS-25. Oak Ridge, TN: Oak Ridge National Laboratory.

Mixon, W. R.; Segaser, C. L. 1976. Energy Conservation Potential of Modular Integrated Utility Systems (MIUS). SAE Report 769094. Washington, DC.

Myers, John G. 1975 (February). "Energy Conservation and Economic Growth-Are They Compatible?" The Conference Board Record. Vol. XII (No. 2): pp. 27-32.

Nalbandian, S. J.; et al. 1978. Commercial Applications of Solar Total Energy Systems. Vols. I-IV. Al-DO E-1 3230. Canoga Park, CA: Rockwell In ternational.

Pollard, William G. 1976 (July/August). "The Long-Range Prospects for Solar Energy." American Scientist. Vol. 64 (No. 4): p. 424. 
Schipper, Lee; Darmstadter, Joel. 1977 (January). What is Energy Conservation? Draft. LBL-5919. Berkeley, CA: Lawrence Berkeley Laboratory.

Schumacher, E. F. 1976. Small is Beautiful. New York: Harper and Row.

Shurr, Sam H.; Darmstadter, Joel. 1976. "The Energy Connection." Resources. Vol. 53: Fall; pp. 1,2, 5-7.

Urban Systems Research and Engineering, Inc. 1978. Preparation of Land Use Energy Consumption Profiles. Washing ton, DC: U. S. Department of Energy, Division of Buildings and Community Systems.

Whaley, T. P. 1979. Applications Analysis of Solar Total Energy Systems to the Residential Sector. Vols. I-IV. ALO-3787-1-4. Chicago, IL: Institute of Gas Technology.

Williams, Harold S. 1977 (October). "Smallness and the Small Town." Small Town. Vol. 8: pp. 7-15.

Wolf er, B. M. 1977 (February). Design Techniques for Modular Integrated Utility Systems. NASA-TM-22005; Washington, DC. 


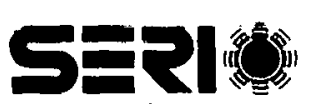




\section{SECTION 6.0}

\section{ENVIRONMENTAL AND SOCIAL IMPACT ASSESSMENT}

Interest in small-scale, decentralized energy systems is related to the desire to adapt energy systems to local environmental and social constraints. This section lists those works that the authors have found to be helpful in understanding how energy technologies may be deployed to disrupt local environmental and social structures as little as possible, or in defining and achieving social and environ mental goals.

Austin, Morris E. 1972 (March). "Land Resource Regions and Major Land Resource Areas of the United States." Agricultural Handbook. No. 196. Washington, DC: Soil Conservation Service.

Balwin, Thomas E.; Dixon-Davis, Diana; Stenehjem, Erik J.; Wolsko, Thomas D. 1976 (August). A Socioeconomic Assessment of Energy Development in a Small Rural County: Coal Gasification in Mercer County, North Dakota. Vol. 1. ANL/AA-5. Argonne, IL: Argonne National Laboratory.

Bailey, Robert G. 1976. Ecoregions of the United States. Ogden, UT: U.S. Forest Service.

Berry, Brian J. L. 1964 (March). "Approaches to Regional Analysis: A Synthesis." Annals of the Association of American Geographers. Vol. 54 (No. 1): pp. 2-11.

Berry, Brian J. L.; Kasarda, John D. 1977. Contemporary Urban' Ecology. New York: Mac millan.

Budnitz, Robert J.; Holdren, John P. 1976. "Social and Environmental Costs of Energy Systems." Vol. 1. Jack M. Hollander and Melvin K. Simmons, eds. Annual Review of Energy. Palo Alto, CA: Annual Reviews, Inc.; pp. 553-580.

Burdge, Rabel J.; Johnson, Sue. 1977. "Sociocultural Aspects of the Effects of Resource Development." Handbook for Environmental Planning: The Social Consequences of Environmental Change. New York: John Wiley; pp. 243-278.

Burcge, Rabel J.; et al. 1978. "Social Components of Environmental Impact Statements." Ravinder K. Jain and Bruce L. Hutchings, eds. Environmental Impact Analysis: Emerging Issues in Planning. Urbana, IL: University of Ilinois Press; pp. 117-132.

California Energy Commission. 1978 (October). Solar Development Program: Draft Environmental Impact Report. Sacramento, C A.

Chalmers, James. 1978. "Usefulness \& Application of Social \& Economic Assessment Models \& Energy Infarmation Exchange in Energy Impact Assessment." Tempe, AZ: Mountain West Research, Inc. 
Clawson, Marion; Stewart, Charles L. 1965. Land Use Infarmation: A Critical Survey of U.S. Statistics Including Possibilities for Greater Uniformity. Baltimore, MD: The Johns Hopkins Press.

Cline, Marlin G. 1949. "Basic Principles of Soil Classification." Soil Science. Vol 67: pp. 81-91.

Comer, C. L.; Sagan, L. A. 1976. "Health Effects of Energy Production and Conversion." Jack M. Holland and Melvin K. Simmons, eds. Annual Review of Energy. Vol. 1. Palo Alto, CA: Annual Reviews, Inc.; pp. 581-600.

Connell, Joseph H.; Slatyer, Ralph O. 1977 (November/December). "Mechanisms of Succession in Natural Communities and Their Role in Community Stability and Organization." The American Naturalist. Vol. 3 (No. 982): pp. 1119-1144.

Cooper, William E.; Vlasin, Raymond D. 1973. "Ecological Concepts and Applications to Planning." Donald 'M. McAllister, ed. Environment: A New Focus for Land-Use Planning. Washington, DC: National Science Foundation; pp. 183-215.

Correll, David L. 1978 (October). "Estuarine Productivity.". Bioscience. Vol. 28: pp. 646-650.

Cronin, L. Eugene. 1967. "The Role of Man in Estuarine Processes." Estuaries. Publication No. 83. Washing ton, DC: American Association for the Advancement of Science; pp. 667-689.

Dasmann, Raymond F. 1976. "Biographic Provinces." CoEvolution Quarterly. No. 11 : Fall; pp. 32-37.

- 1976. Environmental Conservation. 4th Edition. New York: John Wiley.

Davidson, Mark; Grether, Donald; Wilcox, Kenneth. 1977 (February). Ecological Considerations of the Solar Alternative. LBL-5927. Berkeley, CA: Lawrence Berkeley Laboratory.

DeLuca, Donald R. 1977. "Community Structure, Resources, and the Capacity to Respond to Environmental Problems: New Concepts for Social Impact Assessment." Kurt Finsterbusch and C. P. Wolf, eds. Methodology of Social Impact Assessment. Stroudsburg, PA: Dowden, Hutchinson, and Ross; pp. 224-234.

Dickert, Thomas G. 1974. "Methods for Environmental Impact Assessment: A Comparison." Katherine R. Domeny, ed. Environmental Impact Assessment: Guidelines and Commentary. Berkeley, CA: University of California Extension; pp. 137-143.

Dickert, Thomas G.; Sorensen, Jens C. 1974. "Some Suggestions on the Content and Organization of Environmental Impact Statements." Katherine R. Domeny, ed. Environmental Impact Assessment: Guidelines and Commentary. Berkeley, CA: University of California Extension. 
Ellis, Scott L.; et al. 1977 (March). Guide to Land Cover and Use Classification Systems Employed by Western Governmental Agencies. Ft. Collins, CO: Ecology Consultants, Inc.

Fenneman, Nevin M. 1928 (December). "Physiographic Divisions of the United States." Annals of the Association of American Geographers. Vol. 28 (No. 4): pp. 261-353.

MeGraw Hill.

1931. Physiography of the Western United States. New York: McGraw Hill.

1938. Physiography of the Eastern United States. New York:

Finsterbusch, Kurt. 1978 (March). "A General Conceptual Framework for Assessing Social Impacts of Projects and Policies on Communities." Social Impact Assessment. Vol. 27: pp. 3-13.

Flax, Michael J. 1978 (February). Survey of Urban Indicator Data, 1970-1977. Washing ton, DC: The Urban Institute.

Ford, Andrew. 1977 (November). Breaking the Stalemate: An Analysis of Boom Town Mitigation Policies. Los Alamos, NM: Los Alamos Scientific Laboratory.

1978. Testing the Effectiveness of Boom Town Policy Proposals. Los Alamos, NM: Los Alamos Scientific Laboratory.

Frankel, Michael L. 1978 (May). "A Social and Economic Da ta Base for Public Land Use Planning." Social Impact Assessment. Vol. 29: pp. 3-12.

Frankena, Frederick. 1978. "Regional Policy Implications of the Energy Crisis." Seymour Warkov, ed. Energy Policy in the United States: Social and Behavioral Dimensions. New York, NY: Praeger Press; pp. 13-21.

Gilmore, John S. 1976 (February). "Boom Towns May Hinder Energy Resource Development." Science. Vol. 191: pp. 535-540.

Gold, Raymond L. 1978. "Linking Social With Other Impact Assessments." Ravinder K. Jain and Bruce L. Hutchings, eds. Environmental Impact Analysis, Emerging Issues in Planning. Urbana, IL: University of Illinois Press; pp. 105-116.

- 1978. "Toward Social Policy on Regionalizing Energy Production and Consumption." Seymour Warkov, ed. Energy Policy in the United States: Social and Behavioral Dimensions. New York: Praeger Press; pp. 22-32.

Goodman, Daniel. 1975 (September). "The Theory of Diversity-Stability Relationships in Ecology." The Quarterly Review of Biology. Vol. 50 (No. 3): pp. 237-266.

. 1976. "Ecological Expertise." Harold A. Feivelson, Frank W. Snider, and Robert H. Socolow, eds. Boundaries of Analysis: An Inquiry Into the Tocks Island Dam Controversy. Cambridge, MA: Ballinger; pp. 317-360. 
Ham mond, Edwin H. 1964 (March). "Analysis of Properties in Land Form Geography: An Application to Broad-Scale Land Form Mapping." Annals of the Association of American Geographers. Vol. 54 (No. 1): pp. 11-19.

Harte, John. 1977 (May). Energy and the Fate of Ecosystems. Report by the Ecosystem Impacts Resource Group of the Risk/Impact Panel, Committee on Nuclear and Alternative Energy Systems; National Academy of Sciences/National Research Center.

Harte, John; El-Gasseir, Mohamed. 1978 (February). "Energy and Water." Science. Vol. 199: pp. 623-634.

Harte, John; Jassby, Alan. 1978. "Energy Technologies and Natural Communities: The Search for Compatibility." Jack M. Hollander and Melvin K. Simmons, eds. Annual Review of Energy. Vol. 3. Palo Alto, CA: Annual Reviews, Inc.; pp. 101-146.

Heer, John E. Jr.; Hagerty, D. Joseph. 1977. Environmental Assessments and Statements. New York.

Hetman, Francois. 1973. Society and the Assessment of Technology. Paris, France: Organization for Economic Cooperation and Development.

Holcomb Research Institute. 1976. Environmental Modeling and Decision Making: The United States Experience. New York: Praeger.

Holdren, John P. 1978 (March). "Environmental Impacts of Alternative Energy Technologies for California." Paul Craig; et al., eds. Distributed Energy Systems in California's Future: Interim Repart. Vol. 2: pp. 1-63.

Holdren, John P.; Harte, John; Tonnessen, Cathy. n.d. Environmental Data Bases and Integrated Models as Assessment Tools: A Critical Survey of Accomplishments, Potential, and Limitations. Unpublished manuscript.

Holling, Crawford S. 1969. "Stability in Ecological and Social Systems." Brookhaven Symposia in Biology, No. 22. G. M. Woodwell and H. H. Smith, eds. Diversity and Stability in Ecological Systems. Upton, NY: Brookhaven National Laboratory; pp. 128-141.

. 1977. "Myths of Ecology and Energy." Future Strategies for Energy Development. Gatlinberg, TN: Oak Rigge Associa ted Universities.

Holling, Crawford S.; Goldberg, M. A. 1973 (November). "The Nature and Behavior of Ecological Systems." Managing the Environment. EPA-600/5-73-010. Washington DC: U.S. Environmental Protection Agency; pp. 31-36.

Isard, Walter; et al. 1976 (August). "Regional Economic Impacts of Nuclear Power Plants." BNL 50562. Upton, NY: Brookhaven National Laboratory.

Jain, Ravinder K.; Hutchings, Bruce L., eds. 1978. Environmental Impact Analysis: Emerging Issues in Planning. Urbana, IL: University of Illinois Press.

Jain, Ravinder K.; Urban, L. V.; Stacey, G. S. 1977. Environmental Impact Analysis: A New. Dimension in Decision Making. New York, NY: Van Nostrand Reinhold. 
Kerley, Charles R.; Siegrist, Carl. 1978 (September). Hartsville Data and Analysis Book: Phase 1. ORNL/TM-6470. Oak Ridge, TN: Oak Ridge National Laboratory.

Keyes, Dale L. 1976 (April). Land Development and the Natural Environment: Estimating Impacts. Washing ton, DC: The Urban Institute.

Klingebiel, A. A.; Montgomery, P. H. 1973 (January). Land-Capability Classification. Agricultural Handbook, No. 210. Washington, DC: Soil Conservation Service.

Küchler, A. W. 1973. "Problems in Classifying and Mapping Vegetation for Ecological Regionalization." Ecology. Vol. 54 (No. 3): pp. 512-523.

Lauff, George H., ed. 1967. Estuaries. Publication No. 83. Washington, DC: American Association for the Advancement of Science.

Leopold, Luna B.; Clarke, Frank E.; Hanshaw, Bruce B.; Balsley, James R. 1971. A Procedure for Evaluating Environmental Impact. Geological Survey Circular 645 . Washington, DC: U.S. Geological Survey.

Margalef, R. 1963 (November/December). "On Certain Unifying Principles in Ecology." The American Naturalist. Vol. 97 (No. 897).

Martino, Joseph P.; Lenz, Ralph C., Jr.; Chen, Kuei-Lin. 1978 (September). Technology Assessment: An Appraisal of the State of the Art. Dayton, OH: University of Day ton Research Institute.

Mason, Herbert L.; Langerheim, Jean H. 1957 (April). "Language Analysis and the Concept Environment." Ecology. Vol. 38 (No. 2): pp. 325-340.

Matthews, William H., ed. 1976. Outer Limits and Human Needs: Resource and Environmental Issues of Developmental Strategies. Uppsala, Sweden: The Dag Ham marskjöld Foundation.

Miller, Peter D. 1980. "Stability, Diversity, and Equity: Social Issues in Alternative Energy Systems." Report of the Risk and Impact Panel. Washington, DC: Committee on Nuclear and Alternative Energy Systems.

Morrison, Denton E. 1978. "Equity Impacts of Some Major Energy Alternatives." Seymour Warkov, ed. Energy Policy in the United States: Social and Behavioral Dimensions. New York: Praeger Press; pp. 164-193.

Mulligan, Linda W. 1978. "Energy Regionalism in the United States: The Decline of the National Energy Commons." Seymour Warkov, ed. Energy Policy in the United States: Social and Behavioral Dimensions. New York: Praeger Press; pp. 1-12.

Odum, Eugene P. 1969 (April). "The Strategy of Ecosystem Development." Science. Vol. 164: pp. 262-270.

- 1971. Fundamentals of Ecology. 3rd Ed. Philadelphia, PA: Saunders. 
Olsen, Marvin E.; Merwin, Donna J. 1977. "Toward a Methodology for Conducting Social Impact Assessment Using Quality of Social Life Indicators." Kurt Finisterbusch and C. P. Wolf, eds. Methodology of Social Impact Assessment. Stroudsburg, PA: Dowden, Hutchinson, and Ross; pp. 43-63.

Peelle, Elizabeth. 1979. Mitigating Community Impacts of Energy Development: Some Examples for Coal and Nuclear Generating Plants in the United States. Oak Ridge, TN: Oak Rique National Laboratory.

- 1980. "Sociopolitical Impacts of Nuclear and Alternative Energy Systems." Report of the Risk and Impact Panel. Washing ton, DC: Committee on Nuclear and Alternative Energy Systems.

Rappaport, Roy A. 1974. "Sanctity and Adaptation." The CoEvolution Quarterly. Summer; pp. 54-68.

1979. Ecology, Meaning, and Religion. Richmond, CA: North

Atlantle Books.

- 1979. "Energy and the Structure of Adaptation." The CoEvolution Quarterly. Spring; pp. 20-28.

Ross, Peggy J.; Bluestone, Herman; Hines, Fred K. $19 \overline{9} 9$ (May). Indicators of Social Well-Being for U.S. Counties. Rural Development Research Report No. 10. Washington, DC: Economics, Statistics, and Cooperative Services, U.S. Department of Agriculture.

Sevian, Walter A.; Bozzo, Salvador R. 1977 (May). A Data Book for the Geographical Allocation of Future U.S. Energy Supply Facilities by County. Upton, NY: Brookhaven National Laboratory.

Shields, Mark A. 1975 (September). "Social Impact Studies: An Expository Analysis." Environment and Behavior. Vol. 7 (No. 3): pp. 265-284.

Stenehjem, Erik J. 1975 (December). Forecasting the Local Economic Impacts of Energy Resource Development: A Methodological Approach. Argonne, IL: Argonne National Labora tory.

Society of American Foresters. 1954. Forest Cover Types of North America (Exclusive of Mexico). Washing ton, DC: Society of American Foresters.

Stoloff, David; Kemmerer, Rebecca. 1978 (September). "Site Screening to Minimize Socioeconomic Impacts of Power Facilities." Social Impact Assessment. Vol. 33: pp. 2-17.

Turner, A. K.; Coffman, D. M. 1973 (July). "Geology for Planning: A Review of Environmental Geology." Quarterly of the Colorado School of Mines. Vol. 68 (No. 3): pp. 1-127.

UNESCO. 1973. International Classification and Mapping of Vegetation. Paris, France: UNESCO. 
United Nations Environment Programme. 1976 (September). Report on Methodology for Selection of Environmentally Sound and Appropriate Technology. Report on Expert Group Meeting held in Nairobi, Kenya, August 30-September 3.

U.S. Department of Agriculture, Forest Service. 1977 (July). Vegetation and Environmental Features of Forest and Range Ecosystems. Agricultural Handbook No. 475. Washing ton, DC: USDA.

1977. (October). Modified Ecoclass: A Method for Classifying Ecosystems. Draft. Rocky Mountain \& Southwest Regions, Rocky Mountain Forest and Range Experiment Station. Ft. Collins, CO.

U.S. Department of Commerce, Bureau of the Census. 1976. County Business Patterns. Washing ton, DC: U.S. Government Printing Office.

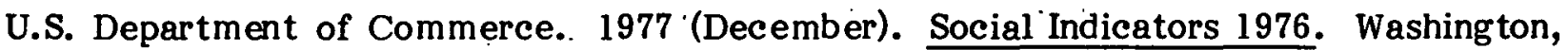
DC: U.S. Government Printing Office.

U.S. Department of the Interior. 1978 (March). Integrated Habitat Inventory and Classification System. Bureau of Land Management Manual, Part 6602. Washington, DC: Bureau of Land Management.

Unseld, Charles T. 1978. "Social Impact Assessment of Energy Policy: Behavior, Life Style, Values, and Priorities." Seymour Warkov, ed. Energy Policy in the United States, Social and Behavior Dimensions, -New York: Praeger.

Van Vor is, Peter. 1975 (December). Ecological Stability: An Ecosystem Perspective. Oak Ridge, TN: Oak Ridge National Labaratory.

Van Zele, Roger. 1980. "Regional Analysis of Energy Development Impacts and Responses: Some Research Methods, Results, and Needs." Report of the Risk and Impacts Panel. Washington, DC: Committee on Nuclear and Alternative Energy Systems.

Vlachos, Evan. 1977. "The Use of Scenarias for Social Impact Assessment." Kurt Finsterbusch and C. P. Wolf, eds. Methodology of Social Impact Assessment. Stroudsburg, PA: Dowden, Hutchinson, and Ross; pp. 211-223.

Vogt, D. P.; Rice, P. L.; Pai, V. P. 1977 (November). Energy Availabilities for Sta te and Local Development: 1973 Data Volume. Oak Ridge, TN: Oak Ridge National Laboratory.

Watkins, George A. 1977. "Development of a Social Impact Assessment Methodology (SIAM)." Kurt Finsterbusch and C. P. Wolf, eds. Methodology of Social Impact Assessment. Stroudsburg, PA: Dowden, Hutchinson, and Ross; pp. 35-42.

Webster, Ronald D. 1978. "Economic Impact Analysis-An Operating System." Ravinder $\mathrm{K}$. Jain and Bruce L. Hutchings, eds. Environmental Impact Analysis: Emerging Issues in Planning. Urbana: University of Illinois Press; pp. 89-97.

Westman, Walter E. 1978 (November). "Measuring the Inertia and Resilience of Ecosystems." Bioscience. Vol 28: pp. 705-710. 
Whittaker, R. H. 1962 (January-March). "Classification of Natural Communities." The Botanical Review. Vol. 28 (No. 1): pp. 2-239.

Wolf, C. P. 1977 (August). "Social Impact Assessment: The State of the Art Updated." Social Impact Assessment. Vol. 20: pp. 3-22. 


\section{SECTION 7.0}

\section{GEOGRAPHICAL SECTIONS}

Sections 7.1 through 7.4 list works on the basis of geographical scale to help researchers and government officials determine what research has been done at a particular level of government or geographical area. These sections are also intended to help government officials and citizens understand decentralized energy systems at the level of analysis (e.g., national policy or community applications) with which they are primarily concerned.

\subsection{NATIONAL}

Clark, Wilson. 1977 (August/September). "Renewable Energy Sources and a Conservation Economy." Ecologist. Vol. 7 (No. 7): p. 283.

Commoner, Barry. 1979. The Politics of Energy. New York: Knopf.

Council on Environmental Quality. 1978 (April). Solar Energy: Progress and Promise. Washing ton, DC: Council on Environmental Quality.

deKieffer, Robert; Levine, Alice. Preliminary Characterization of Selected Decentralized Energy Studies. SERL/ RR-354-452. Golden, CO: Solar Energy Research Institute; forthcoming.

Dierker, Janet. 1978 (August). A Directory of Federal Sources of Infor mation on Solar Energy. Washing ton, DC: Center for Renewable Resources.

Drysdale, Frank R.; Calef, Charles E. 1977 (October). The Energetics of America: An Atlas. BNL 5050-R. Upton, NY: Brookhaven National Laboratories.

Ferrey, Steven. 1978. "How Carter's Solar Program Could Eclipse the Cities." Planning. December; pp. 20-23.

Hayes, Denis. 1977. Rays of Hope: The Transition to a Post-Petroleum World. New York: Norton.

1978 (February). "The Potential for Small-Scale, Decentralized Energy Sources and the Federal Role in Their Development." Proceedings of an Energy Policy Seminar, Graduate Program in Science, Technology, and Public Policy, George Washington University, Washington, DC.

Hughes, J. T.; Aamot, H. W. 1978. Energy Independence at Remote Facilities. Fort Belvoir, VA: U.S. Army, Facilities Engineering Support Agency.

Jhirard, David; Hooevar, Carl. 1977 (November). "Energy Strategies for a Solar-powered United States." University of Miami Nuclear Energy and Alternatives Conference, Miami, FL; November 7-11. Cambridge, MA: Ballinger; p. 573.

Kelly, Henry. 1978. Application of Solar Technologies to Today's Energy Needs, Vols. 1 and II. Washing ton, DC: U.S. Congress, Office of Technology Assessment. 
Kirschner, Linda. 1978. "Decentralization of Electric Power Production: An Overlooked Item on the National Energy Agenda." Energy. Winter; pp. 27-28.

Landsberg, Han H.; et al. 1979. Energy: The Next Twenty Years. Cambridge, MA: Ballinger.

Metz, William D.; Hammond, Allen L. 1978. "Strategies of Research: Making Solar after the Nuclear Model." Solar Energy in America. Washington, DC: American Association for the Advancement of Science; pp. 1-18.

Nodiff, Marvin J. n.d. The Politics of Energy Planning. PCH-l(9). Columbus, OH: Battelle Columbus Laboratories.

Ohi, James M. Decentralized Energy Studies: Research Strategy and Management. SERI/RR-354=447. Golden, C.n: Snlar Finergy Research Institute; forthcoming.

Quinn, James; Ohi, James M. 1980 (May). Decentralized Energy Studies: A Compendium of U.S. Studies, Programs, and Projects. SERI/TR-354-450. Golden, CO: Solar Energy Research Institute.

Savitz, Maxine; Deutsch, John; Thorne, Robert; Beattie, Donald. 1978 (August). DOE Role in Support of Small-Seale Appropriately Distributed Technology. Conf-780132; Washing ton, DC: U.S. Department of Energy.

Schurr, Sam H.; et al. 1979. Energy in America's Future: The Choices Before Us. Baltimore, MD: Johns Hopkins University Press.

Seamans, Robert C. 1976 (November). "Alternative Energy Systems." American Nuclear Society/European Nuclear Society International Conference on World Nuclear Energy; Washing ton, DC: November 14-19; p. 13.

Solar Lobby. 1979 (January). Blueprint for a Solar America. Washington, DC: Solar Lobby.

Stanford Research Institute. 1977. Solar Energy in-America's Future: A Preliminary Assessment. 2nd Ed. Menlo Park, CA: Stanford Research Institute; March.

Steinhart, John S.; et al. 1979. Pathway to Energy Self-Sufficiency: The 2050 Study. San Francisco: Friends of the Earth.

Stobaugh, Robert; Yergen, Daniel. 1979. "After the Second Shock: Pragmatic Energy Stra tegies." Foreign Affairs. Vol. 57 (No. 4): Spring; pp. 836-87.

Stobaugh, Robert; Yergin, Daniel, eds. 1979. Energy Future: Report of the Energy Project of the Harvard Business School. New York: Random House.

Union of Concerned Scientists. 1980. Energy Strategies: Toward a Solar Future. Cambridge, MA: Ballinger.

U.S. Department of Energy. 1978. The Great Adventure. HCP/U6354-01. Washington, DC: U.S. DOE. 
U.S. Department of Energy. 1978. Solar Energy: A Status Report. DOE/ET-0062. Washing ton, DC: U.S. DOE.

1979 (February). Domestic Policy Review and Solar Energy: A Response Memorandum to the President of the United States. TID-22834. Washing ton, DC: U.S. DOE.

U.S. Department of Energy, Office of Conservation and Solar Applications. 1979 (February). Community Systems Program. DOE/CS-0072. Washington, DC: U.S. DOE.

U.S. Department of Energy, Office of Environment. 1979 (October). An Introduction to the Technology Assessm ent of Solar Energy Project. Washington, DC: U.S. DOE.

U.S. Department of Energy, Office of Solar, Geothermal, Storage, and Electric Energy Systems. 1978 (September) Small Scale Technology Study. Draft. Washington, DC: U.S. DOE.

U.S. Department of Housing and Urban Development. 1976. Rapid Growth from Energy Projects-Ideas for. State and Local Action: A Program Guide. Washington, DC: HUD, Office of Community Planning and Development.

U.S. Energy Research and Development Administration. 1977 (July). Proceedings of the Public Meeting to Review the Status of the Inexhaustible Energy Resources Study. Conf. 770715. Washing ton, DC: U.S. ERDA.

U.S. House of Representatives, 94 th Congress, Second Session. 1976. Part I: Middle and Long-Term Energy Policies and Alternatives. Subcommittee on Energy and Power, Committee on Interstate and Foreign Commerce; Washington, DC: U.S. Government Printing Office.

U.S. Senate, 94th Congress, Second Session. 1977 (December). Alternative Long-Range Energy Strategies. Select Committee on Small Business and Committee on Interior and Insular Affairs; joint hearing held on 9 December 1976. Washington DC: U.S. Government Printing Office.

1977 (December). Alternative Long-Range Energy Strategies: Additional Appendices-1977. Select Committee on Small Business and Committee on Interior and Insular Affairs; joint hearing held on 9 December 1976. Washington, DC: U.S. Government Printing Office.

\subsection{MULTSTATE REGION}

Barisa, Susan G.; Ballou, Stephen W. 1978. Regional Energy-Environmental Data Book: Midwest Region. Draft. Argonne, IL: Argonne National Laboratory.

Battelle Pacific Northwest Laboratory. 1978. Regional Energy-Environment Data Book: Northwest Region. PNL-RA P-28. Richland, WA: Battelle.

Copenhaver, E. D.; Olson, R. J.; Rice, P. L. 1978. Regional Energy-Environment Data Book: Southern Region. Draft. Oak Ridge, TN: Oak Ridge National Laboratory. 
Dartmouth College, Resource Policy Center. 1978 (September). Dartmouth/SERI Symposium on the Design of Regional Soft Energy Paths. DSD \#127. Marymount College of Virginia, Arlington, VA; September 12-13, 1978. Hanover, NH: Dartmouth College, Resource Policy Center.

Donovan, L. E.; Keller, J. G.; Kunze, J. F. 1976 (September). Space Heating Systems New and Conventional in the Northwest with Emphasis on Alternate Energy Adaptions. SAE Report 769113.

Frankena, Frederick. 1978 (June). "Regional Socioeconomic Impacts of Declining Net Energy." Urban Ecology. Vol. 3 (No. 2): p. 101.

Friewald, Joyce; et al. 1978. Regional Energy-Environment Data Book: Rocky Mountain Region. Draft. Los Alamos, NM: Los Alamos Scientific Laboratory.

Goodnight, J.; King, S. 1978. The Role of Government in Solar Energy Development: A View fom the Nor thwest. Columbus, OH: Battelle Labaratories.

Munson, James Steven; Stern, Robert. 1978. Regional Energy-Environment Data Book: Northeast Region. Draft. Upton, NY: Brookhaven National Laboratory.

New England Congressional Caucus. 1979. Final Report of the New England Energy Congress: A Blueprint for Energy Action, Executive Summary and Recommendations. Medford, MA: Tufts University.

Page, Abbie. 1979 (May). New England Sustainable Energy Project: A Feasibility Assessment. MTR-3685. Bedford, MA: The MITRE Corporation.

Rudeman, Henry; et al. 1978. An Energy-Environmental Data Book for the States of California, Hawaii, and Nevada. Berkeley, CA: Lawrence Berkeley Laboratory.

Sawyer, J. W. 1977. Environmental Systems Study on the Development of Fossil Fuel Resources in the Southwest. Washing ton, DC: Resources for the Future.

Stone and Webster. 1979. Southeast Regional Assessment Study: An Assessment of the Opportunities for Solar Electric Power Generation in the Southeastern United States. Draft. Washington, DC: U.S. DOE.

U.S. Department of Energy, Office of Environment. 1980 (January). Regional Issue Identification and Assessment: Study Methodology First Annual Report. DOE/EV0063 Washington, DC: U.S. DOE.

1979 (September). Regional Issue Identification and Assessment-First Annual Report. Washing ton, DC: U.S. DOE.

\subsection{STATE}

Byfield, D. A. 1977. Mixed Strategies for Energy Conservation and Alternate Energy Utilization for Buildings in Minnesota. St. Paul, MN. 
California Energy Resources Conservation and Development Commission. 1978. Solar Energy in California: Residential Thermal Applications. Draft. Sacramento, CA: Energy Resources Conservation and Development Commission.

California Office of Appropriate Technology. 1979. Present Value: Constructing a Sustainable Future. Sacramento, CA: Office of Appropriate Technology.

Craig, Paul; et al., eds. 1973 (March). Distributed Energy Systems in California's Future: Interim Report. Vols. I and II. HCP/P7405-03. Washington, DC: U.S. Government Printing Office.

Craig, Paul P.; Levine, Mark D. 1979. Distributed Energy Systems in California's Future: Issues in Transition. Draft. Report No. DES-R-02. Berkeley, CA: Lawrence Berkeley Laboratory.

Darling, R.; Helmann, P. K. 1978. Research, Development and Demonstration. Augusta, ME: State Office of Energy Resources.

Hawaii State Advisory Task Force on Energy Policy. 1975 (February). Alternate Energy Sources for Hawaii. Honolulu, HL University of Hawaii.

Hawaii State Energy/Natural Resources Committees. 1977 (November). A Comprehensive Energy Program for Hawaii. Honolulu, HI: Hawaii Sta te Legislature.

Hyman, Barry; et al. 1978. Policy Analysis of Decentralized Electric-Generating Facilities for Washing ton State. Draft. Seattle, WA: University of Washington, Program on Social Management of Technology.

Montana Energy Office. 1978 (May). The Montana Solar Plan. Helena, MT: Montana Energy Of fice.

National Association of State Purchasing Officials. 1978. Energy Conservation Through Public Purchasing. Washing ton, DC: U.S. Departm ent of Energy, Division of Buildings and Community Systems.

National Governor's Association Subcommittee on Energy Conservation. 1978. Enhanced Conservation Through Public Purchasing. Washington, DC: U.S. Department of Energy, Division of Buildings and Community Systems.

Northwest Regional Planning Commission; Wisconsin Department of Natural Resources. 1979. The Potential for Expanded Use of Wood Fuels in N.W. Wisconsin. Spooner, WI: Northwest Regional Planning Commission.

Roessner, David; et al. 1980 (March). Turning Laws into Incentives: The Implementation of State Solar Energy Incentives. SERI/TR-722-583. Golden, CO: Solar Energy Research Institute.

\subsection{COMMUNITY}

Alexander, W. 1978. Comprehensive Community Planning for Energy Management and Conservation. Columbia, MD: Hittman Associates Inc. 
Allen, Margaret. 1979 (April). Joining Forces: Cooperative Environmental Action by Urban Groups-Cases and Lessons.' Washington, DC: Urban Environment Foundation.

The American Institute of Architects Research Corporation. 1979. The Community Energy Design Primer. Washington, DC: The AIA Research Corporation.

Benson, James. 1979. County Energy Plan Guidebook: Creating a Renewable Energy Future. Fairfax, VA: Institute for Ecological Policies.

Berman, Sam; Bernier, Jacki. 1979. Nonconventional Technologies for Municipal Utilities in Small Communities. Berkeley, CA: Lawrence Berkeley Laboratory; January.

Brookhaven National Laboratory and State University of New York. 1975 (October). Land Use and Energy Utilization. Interim Report. Washington, DC: Federal Energy Administration.

Bureau of Municipal Research. 1979 (March). What Can Municipalities Do About Energy? Toronto, Canada: Bureau of Municipal Research.

Burns, D. R.; Holway, D. K. 1979 (April). "Lawrence Hydroelectric Project-Civil Works and Bulb Turbines." Presented at Am̄èricān Pōwè̄ Confērēence; Aprll 23-25.

Christianson, Mary; et al. 1977 (May). Windmill Power for City People. New York: Energy Task F orce.

Contra Costa County Planning Department. 1976 (May). Energy Conservation Guidelines for Evaluating New Development in Contra Costa County, CA. Martinez, CA: Con tra Costa County Planning Department.

- n.d. Energy Use and Conservation in Contra Costa County. Martinez, CA: Contra Costa County Planning Department.

Curl, Huldah, ed. 1975. Winona: Towards an Energy Conserving Community. Minneapolis, MN: School of Architecture and Landscape Architecture, University of Minnesota.

City of Davis. 1976 (June). Planning for Energy Conservation. Draft. Davis, CA: City of Davis.

1977 (March). Davis Energy Conservation Report: Practical Use of the Sun. Washing ton, DC: U.S. Government Printing Office.

Dommel, Paul R.; et al. 1978 (June). Decentralizing Community Development. HUDPDR-354. Washington, DC: U.S. Department of Housing and Urban Development.

Duff ey-Armstrong, Marilyn; Armstrong, Joe. 1979 (June). Community Impediments to Implementation of Solar Energy. Menlo Park, CA: Stanford Research Institute.

Duran, A. A. 1978. Energy Park and Demonstration Devices. Cheyenne, WY: Community Action Inc. 
Energy Task Force. 1977. No Heat, No Rent. New York: Energy Task Force.

Fels, Margaret Fulton; Munson, Michael J. 1975. "Energy Thrift in Urban Transportation: Options for the Future." Robert H. Williams, ed. The Energy Conservation Papers. Cambridge, MA: Ballinger.

Goodnight, Jill A. 1978 (January). "Community Impact Assessment of a Diversified Geothermal Energy Project Proposed for the Raft River Valley, Idaho." Technology for Energy Conservation National Conference. Albuquerque, NM; January 24-27, 1978 ; p. 342.

Gunn, Anita. 1978 (August). Sources of Funds for Solar Activities. Washington, DC: Center for Renewable Resources.

City of Independence. 1977. Grid-Connected Integrated Community Energy System, Final Report, Vol. I, Executive Summary. Washing ton, DC: U.S. Energy Research and Development Administration.

Institute for Local Self-Reliance. n.d. Planning for Energy Self-Reliance: A Case Study of the District of Columbia. Washing ton, DC: ILSR.

Jashne, Herbert; Karnitz, Michael; Rubin, Alan; Margen, Peter. 1979. (July-September). "District Heating/Cogeneration Application Studies for the Minneapolis-St. Paul Area." District Heating. Vol 65 (No. 1): pp. 26-40.

Johnson, Lee. 1978. "Neighborhood Energy: Designing for Democracy in the 1980s." Lane deMoll and Gigi Coe, eds. Stepping Stones: Appropriate Technology and Beyond. Portland, OR: Schocken Books/R AIN; pp. 174-187.

Kennedy, Allen S.; Sewell, Isaiah O.; Faddis, Roy J.; Lee, Chimmei. 1977 (October). "Economic Analysis of Integrated Community Energy Systems." International Conference on Energy Use Management, Vol. 2. Tucson, AZ: October $\overline{24-28,1977 \text {; }}$ p. 401.

Krass, Alan S.; et al. 1979. Energy Self-Sufficiency Study; Northampton, Mass. Amherst, MA: Hampshire College.

Kron, R.; Davis, A.; Davis, H. 1979 (February). Energy Supply Options for Soldier's Grove, Wisconsin: A Summary of Recommendations. ANL/ICES-TM-32. Argonne, IL: Argonne National Labora tory.

League of California Cities/California Energy Commission. n.d. Solar Handbook for Local Governmnet Officials. Sacramento, CA: California Energy Commission.

Levine, Mark. 1979. St. Louis Case Study: The Potential for Energy Conservation and Renewable Resources. Dráft. Berkeley, CA: Lawrence Berkeley Laboratory.

Livingston, Brian. 1979. Whiteaker's Urban Environment. Eugene, OR: Whiteaker Community Council.

Mathematical Sciences Nor thwest, Inc. 1979 (April). Solar Heating Guidelines, Shadow Run Residential Development, Everett, Washing ton. MSNW-79-3059. Belleveue, WA: Mathematical Sciences Northwest, Inc. 
McKonkey, W. 1978. Alaska State Capital Planning. Juneau, AK: State Department of Commerce and Development.

Miller, Clara G.; Kleinman, Robert; Warren, J. Bartlet. 1978 (December). Energy Technology Assessment Workbook. Corning, NY: Citizen-Based Energy Technology Assessment Program, Southern Tier Central Regional Planning and Development Board.

- 1978 (December). Renewable Energy Technology Handbook. Corning, NY: Citizen-Based Energy Technology Assessment Program, Southern Tier Central Regional Planning and Development Board.

- 1978 (December). Citizen-Based Energy Technology Assessment Program. Corning, NY: Southern Tier Central Regional Planning and Development Boald.

Milne, Murray; Adelson, Marvin; Corwin, Ruthann. 1979 (April). Three Solar Urban Futures: Characterization of a Future Community Under Threc Encrgy Supply Scenarios. Draft. Los Angeles, CA: University of California, Urban Innovations Group.

National Association of Farmworkers Organizations. 1979 (January). Research and Demonstration, Interim Report. Washington, DC: Energy und Ruryl Development, National Association of Farm workers Organization.

OReilly Associates; Petersen, Edward. 1978. Alternative Energy Feasibility Study for the Village of Pulaski, New York.

City of Pasadena; Pasadena Redevelopment Agency; Levine and McCann; Genge Community Consultants. 1977. TIES: Total Integrated Energy System Feasibility Analysis for the Downtown Redevelopment Project, Pasadena, California. Washing ton, DC: U.S. Energy Research and Development Administration.

Pennsylvania Power and Light Company. 1979 (June). Energy Conservation Ideas for Community Planning. Allentown, PA: Pennsylvania Power and Light Co.

Phillips, J. D. 1976. Project Phoenix, Final Report. Colorado Springs, CO: City of Colorado Springs, Department of Public Utilities.

Pomerantz, David; et al. 1979 (April). Franklin County Energy Study: Scenario for the Future. Amherst, MA: Future Studies Program, University of Massachusetts.

City of Portland. 1976. Energy and Land Use. Portland, OR: Portland City Planning Commission.

1977 (June). Energy Conservation Choices for the City of Portland. Portland, OR: Portland Bureau of Planning.

: 1979. Energy Conservation Project. Portland, OR: City of Portland. 
Puffer, Frank W.; Landry, Lawrence; Goble, Robert. 1977. A Preliminary Feasibility Study of a Grid-Connected Integrated Community Energy System at Clark University. Washington, DC: U.S. Energy Research and Development Administration.

Resource Planning Associates, Inc. 1977 (May). Developing and Analyzing a Coordinated Approach to Energy-Related Community Development. Draft. Washington, DC: U.S. Energy Research and Development Administration.

Ridgeway, James; Projansky, Carolyn S. n.d. Energy Efficient Community Planning: A Guide to Saving Energy and Producing Power at the Local Level. Emmaus, PA: JG Press.

Ritschard, Ronald L. 1979 (October). Assessment of Solar Energy Within a Community: Summary of Three Community-Level Studies. Washing ton, DC: U.S. DOE.

City of Riverside. 1979 (January). Integrated Energy Plan for Riverside, California: Final Report; Phase 3. Riverside, CA.

Roberts, James S. 1975. Energy, Land Use, and Growth Policy: Implications for Metropolitan Washing ton. Washing ton, DC: Metropolitan Washington Council of Governments.

Scott, P. C. 1978. Workshops on Energy Costing in Local Planning. Albany, OR: LinnBenton Community College.

Socolow, Robert. 1977 (June). The Twin Rivers Program on Energy Conservation in Housing: A Summary for Policy Makers. Princeton, NJ: Center for Environmental Studies, Princeton University.

THK Associates, Inc. 1979 (October). Energy Conscious Planning: Applications in Air, Water, Land Use, and Transportation Planning for the Denver Metro Area. Denver, CO: THK Associa tes, Inc.

City of Trenton. 1977. Trenton ICES, Volume 1, Phase I, Final Report. Washington, DC: U.S. Energy Research and Development Administration.

Twiss, Robert H.; Smith, Patricia L.; McCreary, Scott T.; Gatzke, Allan E. 1979 (May). Community-Level Environmental Impacts of Decentralized Solar Technologies. Berkeley, CA: Lawrence Berkeley Laboratory.

University of Minnesota. 1977. Grid-Connected Integrated Community Energy System: Executive Summary, Final Repart, Phase I. Washington, DC: U.S. Energy Research and Development Administration.

.Van der Ryn, Sim. 1979. "Hamilton Solar Village (Formerly Hamilton Air Force Base, Marin County, California)." The CoEvolution Quar terly. Fall; pp. 104-113.

Vine, Edward L. 1979. Planning for an Energy Conserving Society: The Davis Experience. Davis, CA: University of California.

Vories, Rebecca; et al. 1979. Reaching Up, Reaching Out: A Guide to Organizing Local Solar Events. SERI/SP-62-326. Golden, CO: Solar Energy Research Institute. 
Welch, Jim. n.d. Wyoming Community Energy Handbook. Chey enne, WY: Wyoming Energy Conservation Office.

Western SUN (California Office). 1979 (June). Capturing the Sun's Energy: Opportunity for Loal Government. Sacramento, CA: Western Solar Utilization Network.

U.S. Converence of Mayors and Institute for the Development of the Urban Arts and Sciences. 1979 (October). Economic Development and Resource Recovery. Draft No. 2. Washing ton, DC: U.S. Conference of Mayors.

U.S. Department of Energy, Office of Policy and Evaluation. 1979 (July). Local Government Energy Activities. 3 volumes. DOE/PE-0015/1. Washington, DC: U.S. DOE.

U.S. House of Representatives, 95th Congress, 2d Sess. Local Energy Policies. Subcommittee on, Energy and Power; Committee on Interstate and Foreign Commerce. Washington, DC: Government Printing Office.

Williams, Harold S.; Hawley, Natalie. 1978. The Corbett Compact. Rensselaerville, NY: The Center for Community Renewal, Institute on Man and Science. 


\section{SECTION 8.0}

\section{AMORY B. LOVINS}

This section is devoted to publications by and about Amory B. Lovins, who, more than any other single individual, has helped to focus national attention on decentralized energy systems.

\subsection{LOVINS, AUTHOR}

Lovins, Amory B. 1973 (May). "Things That Go Pump in the Night." New Scientist. Vol. 58: pp. 564-566.

- 1974. "Energy: Some Constraints and Opportunities." Ambie. Vol. 3 (Nos. 3-4): pp. 123-125.

- 1974. Nuclear Power: Technical Bases for Ethical Concern. London: Earth Resources Research, Ltd.

- 1975. World Energy Strategies: Facts, Issues, and Options. Cambridge, MA: Friends of the Earth/Ballinger.

- 1975 (November). "Social and Ethical Aspects of the Liquid-Metal Fast Breeder Reactor." Symposium on Key Questions About the Fast Breeder Reactor. Delf $t$, the Netherlands: Technisce Hageschool.

1976 (March). "Untangling the Nuclear Debate." Development Forum. Vol. 4 (No. 2): p. 5 .

- 1976 (April). "Nuclear Power for Ontario?" Alternatives. Vol. 5 (No. 2): p. 23.

- 1976. "Long Term Constraints on Human Activity." Environmental Conservation. Vol. 3 (No. 1): Spring; pp. 3-13.

- 1976 (October). "Energy Strategy: The Road Not Taken ?" Foreign Affairs. Vol. 55 (No. 1): pp. 66-96.

- 1977 (July). "Resilience in Energy Strategy." The New York Times.

July 24.

- 1977 (August). "Cost-Risk-Benefit Assessments in Energy Policy." The George Washing ton Law Review. Vol. 45: pp. 911-943.

- 1977. "Limits to Energy Conversion: The Case for Decentralized Technologies." Alternatives to Growth I: A Search for Sustainable Futures. Denn is L. Meadows, ed. Cambridge, MA: Ballinger; pp. 59-78.

Ballinger Press.

1977. Soft Energy Paths: Toward a Durable Peace. Cambridge, MA: 
. 1977 (September). "Invited Testimony for Hearings on the Costs of Nuclear Power." Environment, Energy, and Natural Resources Subcommittee of the Committee on Government Operations, U.S. House of Representatives, 21 Septe mber 1977.

- 1977 (December). "Scale, Centralization and Electrification in Energy Systems." Presented at symposium on Future Strategies of Energy Development; Oak Ridge Associated Universities; Oak Ridge, TN; October. Reprinted in Alternative Long-Range Energy Stra tegies. Joint Hearing, Select Committee on Small Business and Committee on Interior and Insular Affairs, U.S. Senate, 94th Congress, 2nd Session, 9 December 1976. Washington, DC: U.S. Government Printing Office; pp. 218-281.

Age. p. 16 .

1978 (January). "The Roads Diverge: The Choice is Urgent." Solar

1978 (September/October). "How to Finance the Energy Transition." Not Man Apart. Vol 8 (No. 13): p. 8.

- 1978 (September/October). "The Soft Energy Path." Center Magazine. Vol. 11 (No. 5): p. 32 .

- 1978. "Soft Enèrgy Technologles." Juck M. Hulluinder and Melvin IK. Simmons, eds. Annual Review of Energy: Vol. 3. Palo Alto, CA: Annual Reviews, Inc.; pp. 477-517.

- 1979 (February). "Thorium Cycles and Proliferation." Bulletin of the A tomic Scientists. pp. 16-22.

- 1980 (February). "Democracy and the Energy Mobilization Board." Not Man Apart. Vol. 10 (No, 2): pp. 14-15.

Lovins, Amory B.; Price, J. H. 1975. Non-Nuclear Futures: The Case for an Ethical Energy Stra tegy. Cambridge, MA: Friends of the Earth/Ballinger.

Sassin, W.; Lovins, A. B.; Meadows, D.; Penczynski, P. 1977 (September). Which Way To Go. Observations Based on Global Perspectives and Energy Strategies. Laxenburg, Austria: In ternational Institu te for Applied Systems Analysis.

\subsection{LOVINS, SUBJECT}

Braunstein, Helen; Loop, R. D. 1978. "A Dialogue." ORNL Review. Vol. 11 (No. 1): pp. 28-36.

Edison Elec tric Institute. 1977. "Soft vs. Hard Energy Path: A Series of Critical Essays on Amory Lovins' 'Energy Stra tegy: The Road Not Taken?' " Electric Perspectives. No. 3.

Forbes, Ian A. 1977. "Energy Strategy: A Time for Realism." Electric Perspectives. No. 3; pp. 27-35. 
Forbes, Ian A. 1977 (March). "Energy Strategy: Not What But How." Energy Research Group Report.

Friends of the Earth. 1977 (June). "Lovins Pens Proliferation into Plowshares." Not Man Apart. Vol. 7 (No. 11).

Hammond, Allen L. 1977 (August). "The Hard and Soft Technology of Energy." New York Times. August 28; p. E5.

1977 (May). "Soft Technology." Energy Debate: Limits to Growth Revisited?" Science. Vol. 196: pp. 959-961.

Kane, Daniel W. 1977. "A Perspective as to the Total Cost of 'Soft Energy.' " Electric Perspective. No. 3: pp. 12-15.

Kenward, Michael. 1977 (July). "Energy Up the Garden Path." New Scientist. p. 212.

Lapp, Ralph. 1977. "Major Shortcomings of 'Energy Strategy: The Road Not Taken?' " Elec tric Perspectives. No. 3; pp. 41-43.

Meinel, Aden B.; Meinel, Marjorie, P. 1977. "'Soft' Energy Paths: Reality and nlusion." Electric Perspectives. No. 3; pp. 24-27.

Nash, Hugh, ed. 1979. The Energy Controversy: Soft Path Questions and Answers. San Francisco, CA: Friends of the Earth.

Parisi, Anthony J. 1977. (October). "Soft Energy, Hard Choices." New York Times. October 16; Sec. 3; p. 1.

Perry, Harry; Streiter; Sally H. 1978. "Multiple Paths or Energy Policy: A Critique of Lovins' Energy Stra tegy." Energy Communications. Vol. 4 (No. 4): p. 317.

Pickering, George W. 1977. "The Road Not Taken-and Wisely So: A Path Too Soft to Travel:" Electric Perspectives. No. 3: pp. 2-7.

Robertson, J. A. L. 1977. "The Plain Man's Guide to Amory Lovins." Electric Perspeclives. Nu. 3: pp. 21-24.

Safer, Arnold E. 1977. "A Critical Review of 'Energy Strategy: The Road Not Taken?" " Electric Perspectives. No. 3: pp. 18-20.

Simard, Ronald L. 1978 (May). A Critique of Amory Lovins' Soft Energy Path. ORNL/TM-6233. Oak Ridge, TN: Oak Ridge National Laboratory.

Stiefel, Michael. 1979 (October). "Soft and Hard Energy Paths: The Roads Not Taken ?" Technology Review. Vol. 82(No 1): pp. 56-66.

Yulish, Charles B., ed. 1977 (June). Soft vs: Hard Energy Paths: Ten Critical Essays on Amory Lovins' " 'Energy Strategy: The Road Not Taken?' " New York: Charles Yulish Associa tes, Inc. 
S=Ply 


\section{SACTION 9.0}

\section{PERIODICALS}

This section lists periodicals that have nourished interest and knowledge about decentralized energy systems. Publication information is given since many of these periodicals have limited distribution and may be difficult to obtain. These periodicals are an important source of information on local activity in decentralized energy systems.

Alternatives. Quarterly. Trent University, Peterborough, Ontario, Canada.

New perspectives on society and environment.

Alternative Architecture. Bimonthly. Dove Publications; 660 Newport Center Drive, Suite 1220; Newport Beach, CA 92660. Subtitled the "Energy Management Journal."

Alternative Sources of Energy. Bimonthly. Alternative Sources of Energy, Inc.; Rt. 2, Box 90A; Milaca, MN 56353.

Alternative technologies for a decentralized society, appropriate technology, transportation, communications.

Appropriate Technology. Quarterly. Intermediate Technology Development Group; London, England.

Biotimes. Bimonthly. International Biomass Institute; $1522 \mathrm{~K}$ St. N.W., Suite 600; Washing ton, DC 20005.

The use of biomass to increase the energy self-sufficiency of the family farm, farm communities, and rural and urban communities.

Building Conservation. Monthly. Supplement to weekly Building Trades Journal and monthly Consulting Engineer. Elm House; 10-16 Elm St.; London, England WCl XOBP.

Includes infor mation on refurbishment, rehabilitation, and renovation.

Canadian Renewable Energy News. Monthly. CREN Publishing Ltd., P.O. Box 4869, Station E; Ottawa, Ontario, Canada KIS 5B4.

Independent publication reparting on renewable energy and conservation innovations and issues.

CCEM P Newsletter. Argonne National Laboratory, Energy and Environmental Systems Division; Building 11; Argonne, IL 60439.

Newsletter for the Comprehensive Community Energy Management Program sponsored by the U.S. Department of Energy.

CoEvolution Quarterly. POINT; Box 428; Sausalito, CA 94965.

Alternative energy and life-style. 
Comment: Community Energy Talk. Newsletter for the Wyoming Community Grants Program. Energy Conservation Office; Capitol Hill Office Bldg.; 25 th and Pioneer; Cheyenne, WY 82002.

Compost Science/Land Utilization: Journal of Waste Recycling. Bimonthly. JG Press, Inc.; P.O. Box 351; Emmaus, PA 18049.

Critical Mass. Monthly. Journal of the Critical Mass Energy Project; P.O. Box 1538; Washing ton, DC 20013.

Energy and safety.

District Heating. Quarterly. International District Heating Association; 5940 Baum Square; Pittsburgh, PA 15206.

District heating.

Energy and Alternatives. Quarterly. P.O. Box 68 1; Salem, OR 97308.

Solar utilities negotiations.

Energy Conservation Digest. Biweekly. Energy Conservation Digest; 1098 National Press Building; Washing ton, DC 20045.

The Energy Consumer. Monthly. U.S. Department of Energy; Office of Consumer Affairs; Room 8E018; Washing ton, DC 20585.

A national solar strategy and solar resource guide.

The Energy Planning Report. Biweekly. Resources News Service, Inc.; 363 National Press Building; Washing ton, DC 20045.

Habitats Tomorrow. Bimonthly. World Future Society; 4916 St. Elmo Ave.; Washington, DC 20014.

Human Scale. Irregularly. Black Hills Energy Coalition; P.O. Box 267; Deadwood, SD 57732 .

Ecology movement in the Black Hills region.

In Business. Bimonthly. J. G. Press, Inc., P.O. Box 323; 18 South Seventh St.; Emmaus, PA 18049.

On running a human-size business.

The Journal of Community Communications. Quarterly. Village Design; P.O. Box 996; Berkeley, CA 94701

The Joumal of the New Alchemists. Annual. The New Alchemy Institute; P.O. Box 47; W oods Hole, MA 02543.

Development of ecologically derived forms of energy, agriculture, aquaculture, housing, and landscapes. 
Linkages. Monthly. National Center for Appropriate Technology; P.O. Box 3838; Butte, MT 59701.

Appropriate technology, small business network news.

Mother Earth News. Bimonthly. Mother Earth News, Inc.; P.O. Box 70; Hendersonville, NC 28739.

Alternative energy and lifestyle, ecology, doing more with less.

The Neighborhood Works. Semimonthly. Center for Neighborhood Technology; 570 Randolph St; Chicago, IL 60606.

Information service and clearinghouse for energy, environment, food, shelter, waste management, and jobs.

New England Energy Notes. Monthly. Service for Energy Conservation in Architecture; 320 Newbury St; Boston, MA 02115.

Energy activities, development, and legislation in New England.

New Roots. Bimonthly. Northeast Appropriate Technology Network, Inc.; P.O. Box 548, Greenfield, MA 01301.

Self-reliance in the Northeast.

Nexus. Monthly. Colorado Solar Energy Association; P.O. Box 5272, Terminal Annex; Denver, CO 80202.

Communication, solar energy promotion.

Not Man Apart. Semimonthly. Friends of the Earth; 124 Spear St.; San Francisco, CA 94105.

Environment, energy, resource management.

Outlook (formerly Acorn). Monthly. Governors State University; Park Forest South, IL 60466 .

Energy and environment network newsletter.

Public Power. Bimonthly. American Public Power Association; Suite 212, 2600 Virginia Ave., N.W.; Washington, DC 20037.

Journal of publicly owned utilities.

RAIN. Ten times/year. Rain Umbrella, Inc.; 2270 N.W. Irving; Portland, OR 97210.

Journal of appropria te technology. 
Renewable Energy Bulletin. Bimonthly. Multi-Science Publishing Co. Ltd.; London, England.

Review of publications on renewable-energy.

Self-Reliance. Bimonthly. Institute for Local Self-Reliance; 1717 18th St., N.W.; , Washington, DC 20009.

Shawnee Sunshine Gazette. Bimonthly. Shawnee Sunshine Network and Solar Project; 211-1/2 W. Main; Carbondale, IL 62901.

Solar energy, community energy planning, nuclear issues.

Small Farm Energy Project Newsletter. Bimonthly. Center For Rural Affairs; P.O. Box 736; Harting ton, NB 68739.

On energy self-sufficient farms as the future of agriculture.

Small Farmer's Joumal. Quarterly. The Small Farmer's Journal; PO Box 197; Junction City, OR 97448.

Social Impact Assessment. Monthly. Box 587, Canal St. Station; New York, NY 10013.

Soft Energy Notes. Irregularly. International Project for Soft Energy Paths; 124 Spear St.; San Francisco, CA 94105.

Newsletter for the international soft path movement. Reprints of issues March 1978 through July 1979 available in A Reprint of Soft Energy News-Access to Tools for Soft Energy Path Studies. DOE/PE-0016/1. Washington, DC: U.S. DOE; October 1979.

Solar Age. Monthly. Solar Vision, Inc.; Church Hill; Harrisville, NH 03450.

Of ficial magazine of the American section of the International Solar Energy Society.

Solar Energy Digest. Monthly. William B. Edmondson; P.O. Box 17776; San Diego, CA 92117.

Newsletter on practical applications of solar energy as well as news about new applications.

Solar Energy Update. Semimonthly. Technical Information Center; Oak Ridge, TN 37830 .

Abstract journal on energy information.

Solar Flashes. Monthly. San Luis Valley Solar Energy Association; P.O. Box 1284; Alamosa, CO 81101 .

Solar energy activities and news from the San Luis Valley community. 
Solar Living and Solar Greenhouse Digest. Bimonthly. Solar Living and Solar Greenhouse Digest, Inc.; P.O. Box 2626; Flagstaff, AZ 86003.

The Solar News. Monthly. Mid-Atlantic Solar Energy Association; 2233 Gray's Ferry Ave.; Philadelphia, PA 19146.

Solar Utilization News. Monthly. The Alternative Energy Insitute; P.O. Box 3100; Estes Park, CO 80517.

Sun Times. Monthly. Alternative Energy Resources Organization (AERO); 435 Stapleton Building; Billings, MT 59101.

Sun Times. Monthly. Solar Lobby; 1001 Connecticut Ave. N.W.; Washington, DC 20036.

Sun Up: Energy News Digest. Monthly. J. Harrington and Associa tes; P.O. Drawer S; Yucca Valley, CA 92284.

UCAT News and Views. Quarterly. University of California Appropriate Technology Program; 2030 Bainer; University of California, Davis; Davis, CA 95616.

Ways and Means. Bimonthly. Conference on Alternative State and Local Policies; 2000 Florida Ave., N.W.; Washing ton, DC 20009.

Wood and Energy. Monthly. A joint publication of the Society for the Protection of New Hampshire Forests and the Wood Energy Institute; 5 South Sta te Street; Concord, NH 03301 .

Zero. Semiannual. Zero Press; 2255 W. 25 th St.; Los Angeles, CA 90018.

Journal of con temporary Buddhist life and thought. 
SEPl 


\section{SECTION 10.0}

\section{BIBLIOGR APHIES/DIRECTORIES/REVIEWS}

This section lists bibliographies and directories concerned with decentralized energy systems.

Calm, James M.; Sapienza, Gerard R. 1979 (May). Integrated Community Energy Systems Engineering and Design Analysis Bibliography. ANL/CNSV-2. Argonne, IL: Argonne National Laboratory.

Citizens' Energy Project. 1979. Citizens' Energy Directory. Washington, DC: Citizens' Energy Project.

Decker, Craig; Okagaki, Alan; Bossong, Ken. 1978. Appropriate Technology Resources. Report Series No. 30. Washing ton, DC: Citizens' Energy Project.

Gil, Efraim. 1976. Energy Efficient Planning: An Annotated Bibliography. Chicago: American Society of Planning Officials.

Mills, Madolia Massey. 1973. The Potential of Direct Solar Energy in Planning. Monticello, IL: Council of Planning Librarians.

Ryan, J. D.; Reznek, B., eds. 1977. Abstracted Reports and Articles of the HUD Modular Integrated Utility Systems (MIUS) Program. National Bureau of Standards Special Report No. 484. Washing ton, DC: NBS.

Unseld, Charles T.; Crews, Robin. 1979 (December). Residential Solar Energy Users: A Review of Empirical Research and Related Literature. SERITR-354-245. Golden, CO: Solar Energy Research Institute.

Urban Land Institute. 1978 (April). Focus on Conservation: A Project List. Washington, DC: Urban Land Institute.

U.S. Department of Energy. Conservation and Renewable Energy Resource Directory. Washing ton, DC: U.S. DOE, Office of Consumer Affairs.

Wallace, Cissy. 1980 (March). Decentralized Energy Studies: Compendium of International Studies and Research. SERI/RR-354-451. Golden, CO: Solar Energy Research Institute. 


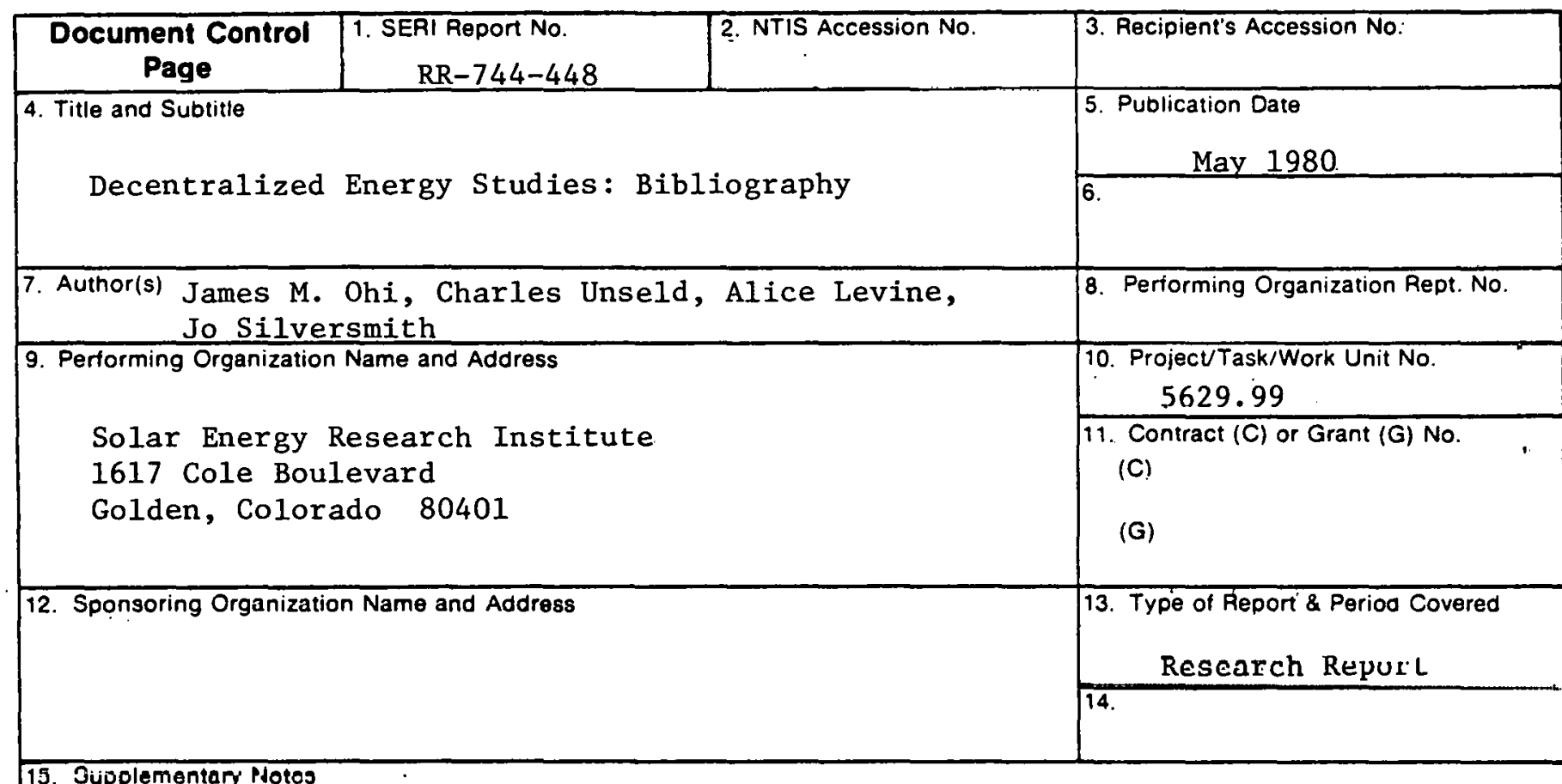

16. Abstract (Limit: 200 words)

This bibliography is a compilation of literature on decentralized energy systems. It is arranged according to topical (e.g., lifestyle and values, institutions, and economics) and geographical scale to facilitate quick reference to specific areas of interest. Also included are articles by and.about Amory B. Lovins who has played a pivotal role in making energy decentralization an important topic of national debate. Periodicals, other bibliographies, and directories are also listed.

17. Document Analysis

a. Descriptors Decentralization ; Bibliography ; Energy Conversion Systems ; Appropriate Technology ; Institutional Factors ; Public Utilities ; Communities ; Land Use ; Planning ; Economics ; Environmental Impacts ; Social Impact

b. Identifiers/Open-Ended Terms

c. UC Categgries

$58 b$

18. Availability Statement

National Technical Information Service

U.S. Department of Commerce

5285 Port Royal Road

Springfield, Virginia 22161

19. No. of Pages

62

20. Price

$\$ 5.25$

Form No. 8200-13 (6-79) 